\title{
Remote Sensing Applications in Water Resources
}

\section{Nagesh Kumar* and T.V. Reshmidevi}

\begin{abstract}
With the introduction of the earth observing satellites, remote sensing has become an important tool in analyzing the Earth's surface characteristics, and hence in supplying valuable information necessary for the hydrologic analysis. Due to their capability to capture the spatial variations in the hydro-meteorological variables and frequent temporal resolution sufficient to represent the dynamics of the hydrologic processes, remote sensing techniques have significantly changed the water resources assessment and management methodologies. Remote sensing techniques have been widely used to delineate the surface water bodies, estimate meteorological variables like temperature and precipitation, estimate hydrological state variables like soil moisture and land surface characteristics, and to estimate fluxes such as evapotranspiration. Today, near-real time monitoring of flood, drought events, and irrigation management are possible with the help of high resolution satellite data. This paper gives a brief overview of the potential applications of remote sensing in water resources.
\end{abstract}

\section{Introduction}

In the earlier days, implementations of conventional methods of hydrologic modeling were hampered by the lack of detailed information about the spatial variability of the physical and hydrological parameters of the catchment. With the evolution of the remote sensing technology, satellite-based remote sensing methods are now being widely used to capture the spatial variation in the hydro-meteorological and catchment characteristics, resulting in significant improvement in the hydrologic modeling.

Major focus of remote sensing applications in hydrology include the estimation of hydrometeorological states (such as land surface temperature, near-surface soil moisture, snow cover, water quality, surface roughness, land use cover), fluxes such as evapotranspiration ${ }^{1}$ and physiographic variables that can influence hydrologic processes. Remote sensing applications in hydrology can be classified into three broad classes: ${ }^{2}$

- Simple delineation of readily identifiable, broad surface features, such as snow-cover, surface water or sediment plumes.
- Detailed interpretation and classification of the remotely sensed data to derive more subtle features, such as specific geologic features or various land-cover types.

- Use of digital data to estimate hydrological state variables (e.g. soil moisture) based on the correlation between the remotely sensed observations and the corresponding point observations from the ground.

Physiographic variables, hydro-meteorological state variables and fluxes estimated using remote sensing techniques have been clubbed with the hydrologic and water quality models to achieve better simulation and understanding of the water budget components and water quality parameters. Such studies have wide range of applications in river morphology analyses, watershed/ river basin management, irrigation planning and management, water conservation, flood monitoring, groundwater studies, and water quality evaluations.

Remote sensing is the science of obtaining information about an object, area or phenomenon without any physical contact with the target of
Department of Civil Engineering, Indian Institute of Science, Bangalore 560012, India. *nagesh@civil.iisc.ernet.in 
investigation. The information is derived by using sensors to measure the Electromagnetic Radiation (EMR) reflected, or emitted by the target. The EMR spectrum is divided into regions or intervals of different wavelengths (called bands) as shown in Figure 1. The bands that are most commonly used in satellite remote sensing include the visible (VIS, wavelength $0.4-0.7 \mu \mathrm{m}$ ), infrared (IR, wavelength $0.7-100 \mu \mathrm{m}$ ) and the microwave regions (wavelength $0.1-100 \mathrm{~cm}$ ). The IR region is further classified as near IR (NIR, 0.7-1.3 $\mu \mathrm{m}$ ), mid IR (MIR, 1.3-3 $\mu \mathrm{m}$ ), and thermal IR bands (TIR, 3-5 $\mu \mathrm{m}$ and $8-14 \mu \mathrm{m}){ }^{3}$

Depending upon the elevation of the sensors from the earth surface, remote sensing may be termed as ground-based remote sensing (sensors are hand-held or mounted on a moving platform), low-altitude or high-altitude areal remote sensing (sensors onboard aircraft), or remote sensing from the space (sensors onboard polar orbiting or geo-stationary satellites).

The sensors used in remote sensing studies can be broadly classified into active and passive sensors. The active sensors (e.g., Radar) send pulses of electromagnetic radiation (specifically, microwave radiations) and record the energy reflected or scattered back. Characteristic of the reflected energy received at the sensor antenna depends on the target properties, its distance from the antenna, and the wavelength of the signals.

Passive sensors only record the energy reflected or emitted by the targets. It can be achieved by using the VIS and IR bands (called optical remote sensing), thermal bands (called thermal remote sensing) or the microwave bands of the EMR spectrum. Landsat Multi-Spectral Scanner (MSS), Thematic Mapper (TM), Enhanced Thematic Mapper (ETM), Indian Remote Sensing (IRS) LISS-3 and P6 are some of the sensors that operate in the VIS and IR spectral ranges. Moderate Resolution Imaging Spectroradiometer (MODIS) onboard NASA's (National Aeronautics and Space Administration) Aqua and Terra satellites uses 36 bands ranging from the VIS to the thermal bands of the EMR spectrum. Sensor that record reflected energy in the microwave bands are also used in remote sensing of the Earth. Special Sensor Microwave/Imager (SSM/I) carried aboard Defense Meteorological Satellite Program (DMSP) satellites is a passive sensor that records microwave radiations. It records microwave radiations in four frequencies raging from $19.35 \mathrm{GHz}$ to $85.5 \mathrm{GHz}$.

The energy reflected by an object varies with the characteristics of the object as well the wavelength of the energy band. In passive remote sensing, energy reflected back in more than one band are recorded, and are used to retrieve information about the target. The approach of measuring the reflectance in more than one band of broad wavelength, using parallel array of sensors, is called multi-spectral remote sensing, and this has been the most common approach in satellite remote sensing. Landsat TM, $\mathrm{ETM}^{+}$, IRS LISS, MODIS are some of the examples for multi-spectral sensors used in the satellite remote sensing.

Recent technological development in passive remote sensing is the use of several narrow, continuous spectral bands, which is called hyperspectral remote sensing. A typical hyper-spectral sensor collects reflectivity in more than 200 channels of EMR spectrum. ${ }^{5}$ For example, the Hyperion sensor onboard the satellite NASA-EO-1 provides data in 220 spectral bands in the range $0.4-2.4 \mu \mathrm{m}$.

There are many papers that give detailed review of the remote sensing applications in the water resources. Most of these papers discuss the role of the remote sensing techniques for any one particular application viz., estimation of rainfall, ${ }^{6,7}$ land surface evaporation, ${ }^{8}$ water quality, ${ }^{9-11}$ runoff, ${ }^{12}$ flood, ${ }^{13}$ and drought ${ }^{14}$ management, and applications in irrigated agriculture. ${ }^{15,16}$ Several studies are also available evaluating the multi-dimensional applications of remote sensing in water resources assessment and management. ${ }^{1,17}$ With remote

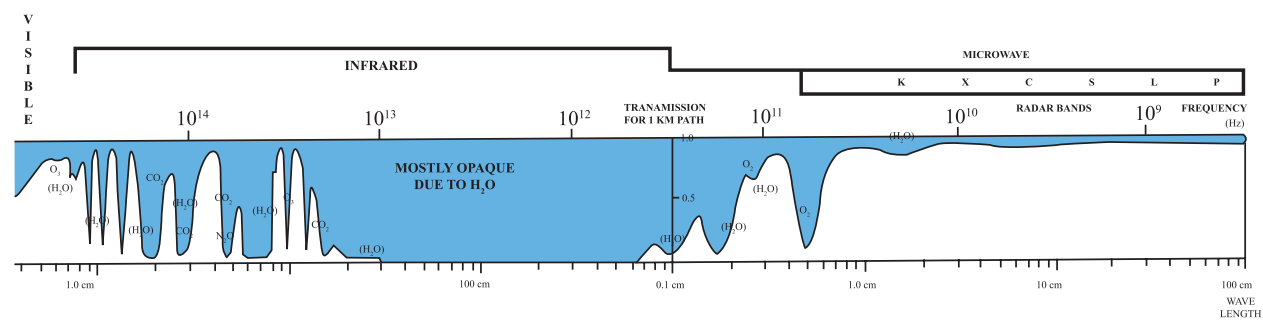

Figure 1: Bands in the EMR spectrum that are commonly used in the remote sensing (Modified from Short, 19994) 
sensing technology evolving at a very rapid rate, many sensors and algorithms are coming up making significant advancement in the water resources applications. This paper presents a concise overview of a broad range of application of the remote sensing technologies in water resources, summarized under three broad classes:

- Water resources mapping

- Estimation of the hydro-meteorological state variables and fluxes

- Applications of the remote sensing data in water resources management

Under each section, details of the sources of global remote sensing data products, if any, are also included.

\section{Water Resources Mapping}

Identification and mapping of the surface water boundaries has been one of the simplest and direct applications of the remote sensing in water resources studies. Optical remote sensing of water resources is based on the difference in spectral reflectance of land and water. Figure 2 shows the reflectance curves of water, vegetation and dry soil in different wavelengths.

Water absorbs most of the energy in NIR and MIR wavelengths, whereas vegetation and soil have a higher reflectance in these wavelengths. Thus, in a multi-spectral image, water appears in darker tone in the IR bands, and can be easily differentiated from the land and vegetation. Figure 3 shows images of a part of the Krishna river basin in different bands of the Landsat ETM+. In the

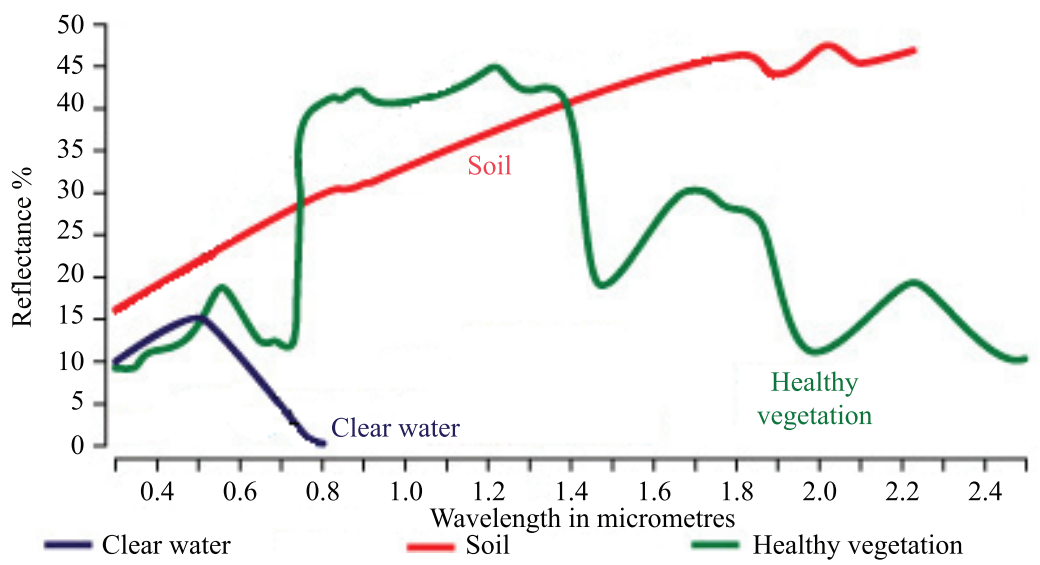

Figure 2: Spectral reflectance curves of different land cover types (Modified from http://www.rsacl.co.uk/ rs.html).
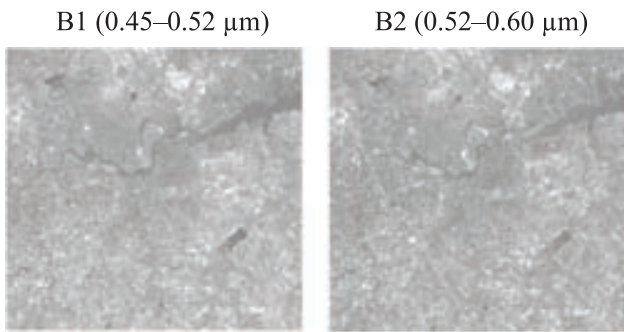

True Colour Composite

B5 $(1.55-1.75 \mu \mathrm{m})$

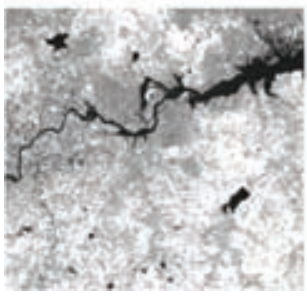

(B: $1,2,3)$

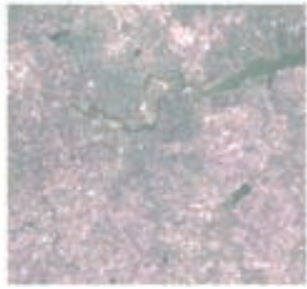

B3 $(0.63-0.69 \mu \mathrm{m})$

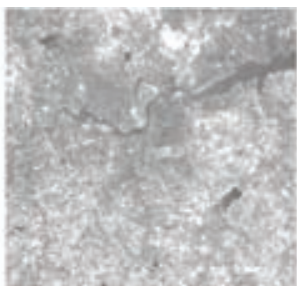

Standerd False Colour Composite (B:2,3,4)

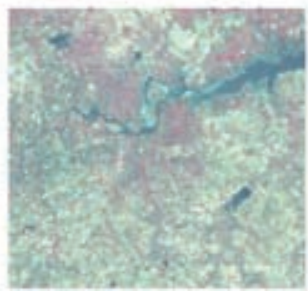

B4 $(0.76-0.90 \mu \mathrm{m})$

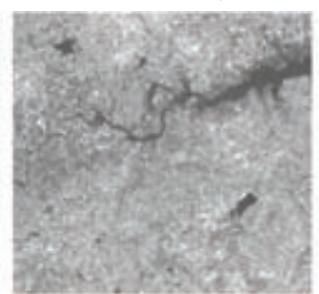

False Colour Composite (B:3,4,5)

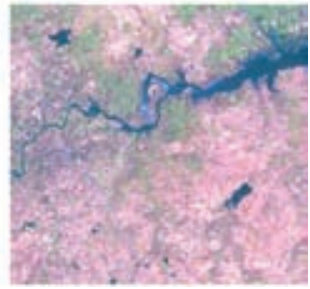

Figure 3: Landsat ETM+ images of a part of the Krishna river basin in different spectral bands. 
VIS bands (bands 1,2 and 3) the contrast between water and other features are not very significant. On the other hand, the IR bands (bands 4 and 5) show a sharp contrast between them due to the poor reflectance of water in the IR region of the EMR spectrum.

Mapping of the surface water bodies using remote sensing techniques finds applications in the areas of flood monitoring, water resources monitoring, and watershed management studies, which are explained in Section 4 in this paper. Water resources mapping requires remote sensing data of fine spatial resolution so as to achieve accurate delineation of the boundaries of the water bodies or inundated areas. Mapping of surface water resources in Jodhpur District in India is a good example for the application of satellite remote sensing for the water resources mapping, in which water bodies up to 0.9 ha surface area have been mapped with the help of Landsat TM images of $30 \mathrm{~m}$ spatial resolution. ${ }^{18}$ With the help of very fine resolution images like IKONOS and SPOT images, with less than $1 \mathrm{~m}$ spatial resolution, further accurate mapping of the water resources can be achieved.

Optical remote sensing techniques, though provide very fine spatial resolution, are less capable of penetrating through the cloud, which limit their application in bad weather conditions. This is particularly a problem in the tropical regions, which are characterized by frequent cloud cover. Also, this limits the optical remote sensing applications in flood monitoring, since floods are generally associated with bad weather conditions. Another major limitation of optical remote sensing is the poor capability to map water resources under thick vegetation cover.

Use of active microwave sensor helps to overcome these limitations to a large extent. Radar waves can penetrate the clouds and the vegetation cover (depending upon the wavelength of the signal and the structure of the vegetation). Water surface provides a specular reflection of the microwave radiation, and hence very little energy is scattered back compared to the other land features. The difference in the energy received back at the radar sensor is used for differentiating, and to mark the boundaries of the water bodies. Radar remote sensing has been used successfully to mark the surface water bodies $^{19}$ and flooded areas under thick forest. ${ }^{20-22}$

Another important development is the use of thermal bands for detecting the boundaries of the water bodies through thick vegetation. ${ }^{23}$ The method used brightness temperature $\left(T_{B}\right)$ measurement using TIR band (10.5-12.5 $\mu \mathrm{m})$ of the Meteosat. The $T_{B}$ data was processed to obtain the thermal maximum composite data (Tmax), and the areas showing lower values of Tmax were marked as the inundated areas. The method was successfully applied to monitor the inundated areas for Lake Chad, in central Africa. The method is advantageous in cases where very frequent data is required (temporal frequency of the data is $30 \mathrm{~min}$.). On the other hand, the poor spatial resolution $(5 \mathrm{~km})$ of the data is the major drawback of the methodology.

\section{Estimation of Hydro-Meteorological State Variables}

Hydrological processes are highly dynamic in nature, showing large spatio-temporal variations. Conventional methods for the estimation of the hydrologic state variables are based on the in-situ or point measurement. Enormous instrumental requirements, manual efforts and the physical inaccessibility of the areas often limit the observed data availability to only a few points within a catchment, and a very poor temporal coverage. These point observations are generally interpolated to derive the spatially continuous data. Capability of the resultant data to capture the spatio-temporal dynamics is largely constrained by the spatial and temporal frequency of the observation. Application of the remote sensing techniques in estimating the hydro-meteorological state variables is a major leap in technology that significantly improved the hydrologic simulations.

This section briefly explains the application of remote sensing techniques for the estimation of the hydrologic state variables such as rainfall, snow and water equivalent, soil moisture, surface characteristics and water quality parameters.

\subsection{Rainfall}

Conventional methods of rainfall measurement using a network of rain gauges suffer a major drawback due to inappropriate spatial coverage required to capture spatial variation in the rainfall. Physical accessibility is one of the major factors that limits density of the rain gauges over remote areas as well as over oceans. Application of the remote sensing techniques helps to overcome the issue of spatial coverage. Sensors operating from the areal or space borne platforms are better capable of capturing the spatial variation over a large area. Remote sensing techniques have been used to provide information about the occurrence of rainfall and its intensity. Basic concept behind the satellite rainfall estimation is the differentiation of precipitating clouds from the non-precipitating clouds ${ }^{24}$ by relating the brightness of the cloud observed in the imagery to the rainfall intensities. 
The earlier methods of satellite rainfall estimation were based on the optical remote sensing, where VIS, IR, and water vapor bands were used to identify the precipitating clouds. High spatial resolution $(\sim 30 \mathrm{~m})$ and the possibility of frequent temporal sampling from space are the advantages of the optical remote sensing. Several algorithms are documented in literature for rainfall estimation using the VIS and IR bands. More than 20 such methods from various sources have been listed by Gibson and Power. ${ }^{24}$ GEOS Precipitation Index (GPI), RAINSAT, FAO, CROPCAST, and ADMIT are a few of them. Since the relationship between cloud brightness observed using the VIS bands and the rainfall is poor, in these methods the VIS imagery is used in conjunction with the IR observations. IR observations, particularly Cloud Top Temperature (CTT), are very significant in satellite rainfall estimation, since the heavier rainfall events are generally associated with larger and taller clouds, and hence colder cloud tops. For example, the GPI algorithm uses a direct relationship between the CTT and the tropical rainfall as shown below: ${ }^{25}$

$G P I(m m)=3 F_{c} t$ where GPI is the rainfall estimates, $F_{c}$ is the fractional cloudiness which is the fractional coverage of IR pixels colder than $235 \mathrm{~K}$ in a $2.5^{\circ} \times 2.5^{\circ}$ box, and $t$ is the time in hours for which the fractional cloudiness is estimated.

Table 1 lists some of the important satellite rainfall data sets, satellites used for the data collection and the organizations that controls the generation and distribution of the data.

Microwave remote sensing using both passive and active sensors (radar) has also been largely used for the estimation of instantaneous precipitation. Use of radar in rainfall simulation has been reported since the late $1940 s^{26,27}$ In radar rainfall estimation, microwave back scatter from the clouds are recorded, and the relations between the radar reflectivity of the cloud and the rain rate was used to estimate the rainfall. Advantages of the radar system are the following: ${ }^{28}$

- Capability to operate in all weather conditions

- Capability to scan a large area within a short duration

- Ability to provide finer temporal resolution data including information about the formation and movement of the precipitation system

Table 1: Details of some of the important satellite rainfall products.

\begin{tabular}{|c|c|c|c|c|}
\hline Program & Organization & Satellites involved & Spectral bands used & Characteristics and source of data \\
\hline $\begin{array}{l}\text { World } \\
\text { Weather } \\
\text { Watch }\end{array}$ & WMO & $\begin{array}{l}\text { EUMETSAT } \\
\text { GEOS, MTSAT } \\
\text { NOAA-19 }\end{array}$ & VIS, IR & $\begin{array}{l}1-4 \text { km spatial, and } 30 \text { min. temporal } \\
\text { resolution } \\
\text { (http://www.wmo.int/pages/prog/ } \\
\text { www/index_en.html) }\end{array}$ \\
\hline TRMM & NASA JAXA & TRMM & $\begin{array}{l}\text { VIS, IR } \\
\text { Passive \& active } \\
\text { microwave }\end{array}$ & $\begin{array}{l}\text { Sub-daily, } 0.25^{\circ}(\sim 27 \mathrm{~km}) \text { spatial } \\
\text { resolution } \\
\text { (ftp://trmmopen.gsfc.nasa.gov/pub/ } \\
\text { merged) }\end{array}$ \\
\hline PERSIANN & CHRS & $\begin{array}{l}\text { GEOS-8, 10, GMS, } \\
\text { Metsat, TRMM, } \\
\text { NOAA-15,16,17 } \\
\text { DMSP F-13,14, } 15\end{array}$ & IR & $\begin{array}{l}0.25^{\circ} \text { spatial resolution } \\
\text { Temporal resolution: } 30 \text { min. } \\
\text { aggregated to } 6 \text { hrs. } \\
\text { (http://chrs.web.uci.edu/persiann/) }\end{array}$ \\
\hline CMORPH & NOAA & $\begin{array}{l}\text { DMSP F-13,14,15 } \\
\text { NOAA-15,16, } 17,18 \\
\text { AQUA, TRMM }\end{array}$ & Microwave & $\begin{array}{l}0.08 \text { deg }(8 \mathrm{~km}) \text { spatial and } 30 \text { min. } \\
\text { temporal resolution } \\
\text { (http://www.cpc.ncep.noaa. } \\
\text { gov/products/janowiak/cmorph_ } \\
\text { description.html) }\end{array}$ \\
\hline
\end{tabular}

Acronyms

CHRS: Center for Hydrometeorology and Remote Sensing, University of California, USA

CMORPH: Climate Prediction Center (CPC) MORPHing technique

DMSP: Defense Meteorological Satellite Program

EUMETSAT: European Organization for the Exploitation of Meteorological Satellites

GEOS: Geostationary Operational Environmental Satellite, USA

GMS: Geostationary Meteorological Satellite, Japan

JAXA: Japan Aerospace Exploration Agency

MTSAT: Multifunctional Transport Satellites, Japan

NASA: National Aeronautics and Space Administration, USA

NOAA: National Oceanic and Atmospheric Administration, USA

PERSIANN: Precipitation Estimation from Remotely Sensed Information using Artificial Neural Network

TRMM: Tropical Rainfall Measuring Mission

WMO: World Meteorological Organization 
In passive microwave remote sensing, $T_{B}$ of the clouds are recorded using passive microwave radiometers (e.g., Special Sensor Microwave Imager, $\mathrm{SSM} / \mathrm{I})$, which is then related to the precipitation rate. ${ }^{29}$ However, poor spatial resolution (of the order of a few $\mathrm{km}$ ) is a major limitation of the passive microwave images.

Satellite rainfall products find applications in the areas of hydrologic modeling, flood and drought monitoring, as mentioned in Section 4.

\subsection{Snow cover and water equivalent}

Periodic snow cover depth and extent, which are some of the essential information required for the snow melt runoff forecasting, are often very much limited mostly due to the physical accessibility to the Snow Cover Areas (SCA). Satellite remote sensing, with its capability to provide images of the snow covered areas at fine spatial and temporal resolution, is becoming a vital tool for the near-real time monitoring of the SCA with good accuracy. Satellite remote sensing of SCA mapping includes optical as well microwave (both passive and active) remote sensing techniques. Table 2 gives a list of satellites/sensors used for snow mapping and the spectral ranges used.

Optical remote sensing using the VIS and NIR bands is the most commonly used approach for SCA mapping. Finer spatial resolution of the images is the major advantage of the optical remote sensing. However, cloud cover commonly observed over SCA is generally one of the major hindrances in optical remote sensing. Active microwave remote sensing (e.g., Synthetic
Aperture radar, SAR) has been adopted in many studies to overcome this problem. ${ }^{34,35}$ Glacier mapping using SAR is based on the difference in backscattering of the microwave signals by the snow and that by the bare ground. When snow is wet, the attenuation from the snow becomes dominant leading to a low backscattering. Thus, the difference between bare ground and wet snow is easily identifiable. Nevertheless, dry snow does not change the backscattering significantly compared to the bare ground, and hence discriminating dry snow areas from the surrounding land masses is difficult using radar remote sensing. On the other hand, optical remote sensing is advantageous for mapping dry snow cover.

Another approach in snow mapping is the use of passive microwave imaging. Microwave signals reflected from the surface are used to estimate the brightness temperature of the surface, using which the snow depth, snow extent and snow water equivalent are estimated. ${ }^{1}$ Snow Water Equivalent (SWE) is related to the brightness temperature and can be obtained using the following relationship: ${ }^{1}$

$\mathrm{SWE}=A+B \frac{T_{B}\left(f_{1}\right)-T_{B}\left(f_{2}\right)}{f_{2}-f_{1}}$

where $A$ and $B$ are the regression coefficients, $T_{B}$ is the brightness temperature and $f_{1}$ and $f_{2}$ are the frequencies of the low scattering and high scattering microwave channels, respectively.

Passive microwave data is advantageous over optical remote sensing due to their capability to penetrate through the cloud cover. Reduced cost

Table 2: List of satellites/sensors that are most commonly used for snow mapping

\begin{tabular}{lllll}
\hline Sensor & Satellite & Spectral bands & Characteristics & References \\
\hline SMMR & Nimbus-7 & Passive microwave & $\begin{array}{l}\text { Daily data at } 25 \mathrm{~km} \text { spatial } \\
\text { resolution }\end{array}$ & 30 \\
AMSR-E & AQUA & Passive microwave & $\begin{array}{l}\text { Daily data at } 12.5 \mathrm{~km} \text { spatial } \\
\text { resolution }\end{array}$ & 31 \\
Landsat TM & Landsat & VIS NIR & $\begin{array}{l}30 \mathrm{~m} \text { spatial resolution, revisit } \\
\text { period is } 16 \text { days }\end{array}$ & 32 \\
AVHRR & NOAA & VIS, NIR & $\begin{array}{l}\text { Daily data at } 1 \mathrm{~km} \text { spatial } \\
\text { resolution }\end{array}$ & 33 \\
MODIS & Terra & VIS, NIR & $\begin{array}{l}\text { Daily data at 250 m spatial } \\
\text { resolution }\end{array}$ & 34 \\
$\begin{array}{l}\text { SAR and } \\
\text { Polarimetric SAR }\end{array}$ & ERS-1 and 2, & Active microwave & $\begin{array}{l}8-100 \mathrm{~m} \text { spatial resolution } \\
\text { Repeat cycle is 24 days }\end{array}$ & $35-38$ \\
\hline
\end{tabular}

Acronyms

AMSR-E: Advanced Microwave Scanning Radiometer-Earth Observing System

AVHRR: Advanced Very High Resolution Radiometer

ERS: European Remote Sensing Satellite

MODIS: Moderate Resolution Imaging Spectroradiometer

SAR: Synthetic Aperture Radar

SMMR: Scanning Multichannel Microwave Radiometer 
involved and availability of global coverage using passive microwave sensors are the advantages of passive microwave imaging over the radar remote sensing for snow mapping. However, the poor spatial resolution is a major limitation of the passive microwave image application in SCA mapping.

With the introduction of remote sensing technology in snow mapping, global level, daily snow cover maps are now available by aggregating the data available from multiple satellites. Daily maps of global snow cover at about $4 \mathrm{~km}$ spatial resolution is now available from NOAA by combining IR and microwave data from multiple satellites including NOAAs GOES Imager and Polar Orbiting Environmental Satellites (POES) AVHRR, US Air Force DMSP/SSMI and EUMETSAT MSG/ SEVIRI sensors. Figure 4 shows the snow depth data over United States on 9th March 2013, obtained from the NOAA.

\subsection{Soil moisture estimation}

Remote sensing techniques of soil moisture estimation are advantageous over the conventional in-situ measurement approaches owing to the capability of the sensors to capture spatial variation over a large aerial extent. Moreover, depending upon the revisit time of the satellites, frequent sampling of an area and hence more frequent soil moisture measurement are feasible. Remote sensing of the soil moisture requires information below the ground surface and therefore spectral bands which are capable of penetrating the soil layer are essential. Remote sensing approaches for soil moisture estimation are mostly confined to the use of thermal and microwave bands of the EMR spectrum.

Remote sensing of the soil moisture is based on the variation in the soil dielectric constant, and in turn $T_{B}$, caused due to the presence of water. However, in addition to the soil moisture content, $T_{B}$ is influenced by the surface geophysical variables such as vegetation type, vegetation water content, surface roughness, surface temperature, soil texture etc. ${ }^{39}$ which makes remote sensing of soil moisture a difficult task. Vegetation canopies partially absorb and reflect the emissions from the soil surface. General algorithms used to incorporate the vegetation influence in soil moisture estimation can be grouped into three: ${ }^{40}$ statistical techniques, forward model inversion and explicit inverse methods. The statistical techniques are based on the regression analysis between $T_{B}$ and soil moisture for different land cover types. In the forward model inversion approach, the model is initially developed to estimate the remote sensing parameter (e.g., $T_{B}$ ) using the land surface parameters (e.g., soil moisture, canopy cover, surface roughness etc.), which is then inverted to estimate the land surface parameters using the actually observed remote sensing parameter. The third

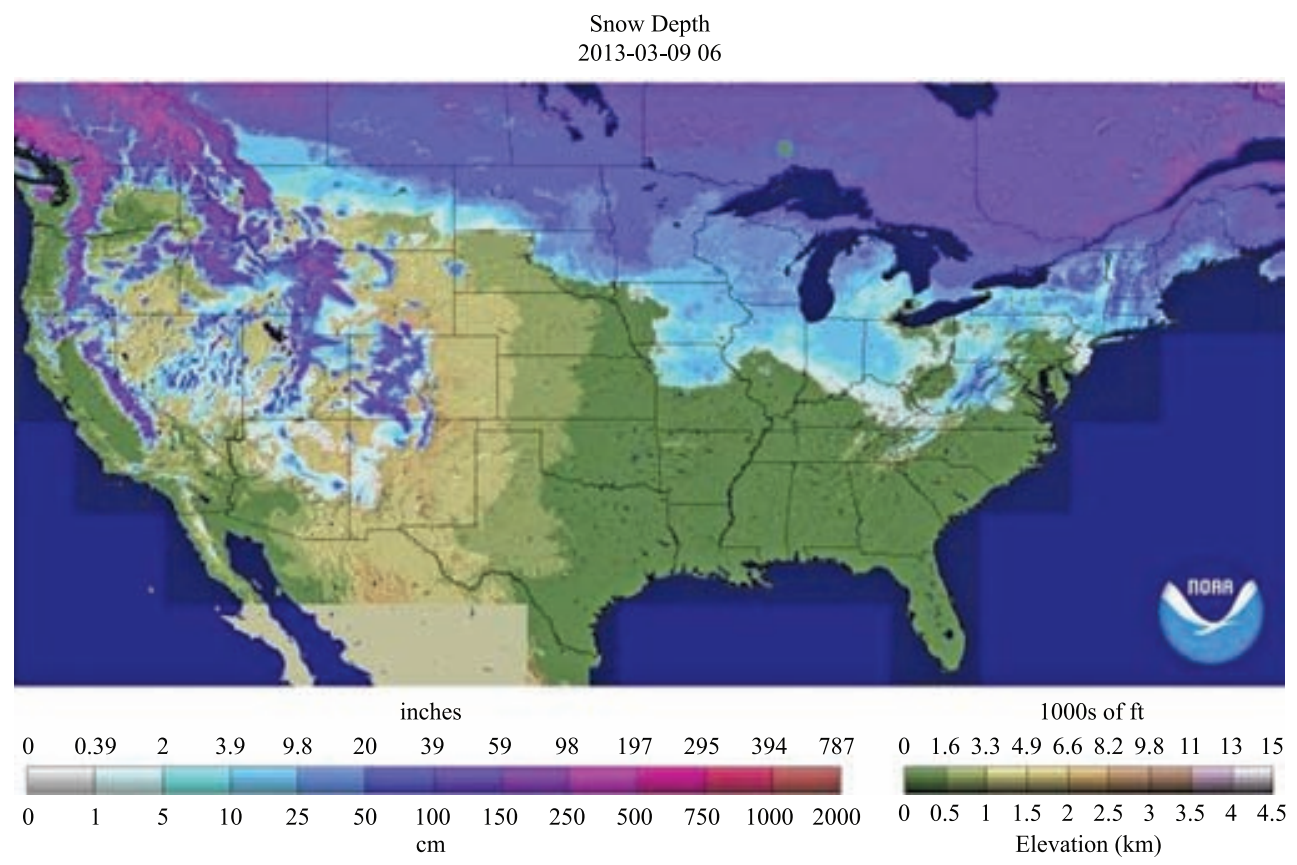

Figure 4: Map of snow depth over United States on 9th March, 2013, generated using the data from multiple satellites.

Source: http://www.eldoradocountyweather.com/climate/world-maps/world-snow-ice-cover.html 
type, explicit inverse method, uses explicit inverse functions to directly transfer the remotely sensed parameters into the land surface parameters.

Remote sensing of the soil moisture using the thermal bands is achieved by interpreting the effect of soil moisture on thermal inertia of the land surface. ${ }^{41}$ For example, Cai et al. ${ }^{42}$ used a thermal inertia model to estimate the soil moisture in the North China Plain using the surface temperature estimation from the MODIS sensor onboard Terra satellite. The soil moisture map derived from the MODIS data was found to be showing only $4.32 \%$ difference from the in-situ measurement and has been considered as a promising algorithm for soil moisture estimation. However, poor capability of the thermal wavelengths to penetrate the vegetation and the coarse spatial resolution are some of the major drawbacks of the thermal remote sensing in soil moisture mapping.

Use of passive microwave radiometers ${ }^{43-47}$ and active radar instruments such as $\mathrm{SAR}^{48,49}$ are the most commonly adopted approaches for the remote sensing of the soil moisture. A large number of studies conducted in the past have proven the usefulness of the microwave signals to determine the moisture content of the surface soil layer. Microwave bands having wavelengths ranging from $0.3 \mathrm{~cm}$ to $30 \mathrm{~cm}$ are considered to be effective in the soil moisture measurement. Wagner et al..$^{50}$ mentioned that the microwave $\mathrm{L}$ band (wavelength 15-30 cm), C band (wavelength 3.8-7.5 cm), and $\mathrm{X}$ band (wavelength $2.5-3.8 \mathrm{~cm}$ ) are the most important bands for soil moisture estimation.

Major limitation of the microwave remote sensing in soil moisture estimation is the poor surface penetration of the microwave signals. Surface penetration capacity of the microwave signals varies with the wavelength of the signal. Several previous studies have shown that microwave signals can penetrate the surface of thickness up to $1 / 4$ th of the signal wavelength. ${ }^{51,52}$ Therefore, the microwave remote sensing is considered to be effective in retrieving the moisture content of the surface soil layer of maximum $10 \mathrm{~cm}$ thickness. However, in hydrologic analysis soil moisture in the entire root zone is important. In the recent years, attempts have been made to assimilate the remote sensing derived surface soil moisture data with physically based distributed models to simulate the root zone soil moisture. For example, Das et al. ${ }^{53}$ used the Soil-Water-AtmospherePlant (SWAP) model for simulating the root zone soil moisture by assimilating the aircraft-based remotely sensed soil moisture into the model.

Another major concern in the passive remote sensing application is the poor spatial resolution.
Passive microwave remote sensing employs larger wavelengths, and hence smaller frequencies, resulting in coarser spatial resolution $(10-20 \mathrm{~km})$ of the images. ${ }^{54}$ However, the wider swath widths (more than $1000 \mathrm{~km}$ ) of the images help to attain frequent temporal coverage (once in every 4-6 days on an average). ${ }^{55}$ Some of the satellite-based passive microwave sensors used for soil moisture measurement include SMMR, AMSR-E and SSM/I. Data from the AMSR-E sensor onboard Aqua satellite has been used to derive daily soil moisture data at a spatial resolution of $0.25^{\circ}$.

In active remote sensing, even though, a fine spatial resolution $(<30 \mathrm{~m})$ is possible with the use of SAR instruments, temporal coverage of the images is very poor. For example, repeat cycle of the ERS satellites used for the soil moisture studies is 35 days. Advanced SCATterometer (ASCAT) aboard the EUMETSAT MetOp satellite is another active microwave sensor used for soil moisture estimation. ASCAT soil moisture data is based on the radar back scatter measurement in the microwave $\mathrm{C}$ band. The data gives soil moisture in the topmost $5 \mathrm{~cm}$ of the soil for the period 2007-2011, at 5 days interval and at $0.1^{\circ}$ spatial resolution. The data is available for the entire land masses except the area covered by snow, and can be obtained from the Institute of Photogrammetry and Remote Sensing, Vienna University of Technology. The active microwave remote sensing data from the Vienna University of Technology were combined with the passive remote sensing data from the Nimbus 7 SMMR, DMSP SSM/I, TRMM TMI and Aqua AMSR-E sensors under the Climate Change Initiative (CCI) of the European Space Agency (ESA). The integrated product, CCI soil moisture data, is available at near global scale with $0.25^{\circ}$ spatial resolution for the period 19792010. The data can be obtained from ESA-CCI website. Figure 5 shows the global average monthly soil moisture in May extracted from the integrated soil moisture data base of the ESA-CCI.

Use of hyper-spectral remote sensing technique has been recently employed to improve the soil moisture simulation. Hyper-spectral monitoring of the soil moisture uses reflectivity in the VIS and the NIR bands to identify the changes in the spectral reflectance curves due to the presence of soil moisture. ${ }^{56}$ Spectral reflectance measured in multiple narrow bands in the hyperspectral image helps to extract most appropriate bands for the soil moisture estimation, and helps to capture the smallest variations. Also, the hyperspectral images provide fine spatial resolution $(\sim 30 \mathrm{~m})$, making it possible to monitor the spatial variation in soil 


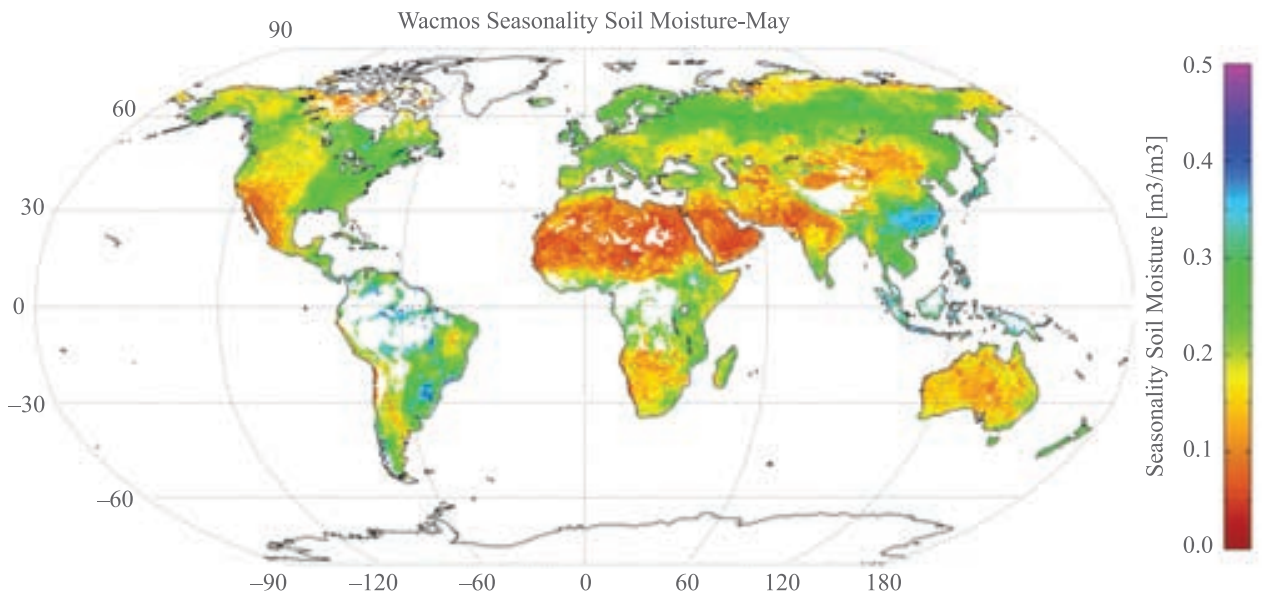

Figure 5: Global monthly average soil moisture in May from the $\mathrm{CCl}$ data. Source: http://www.esa-soilmoisture-cci.org/

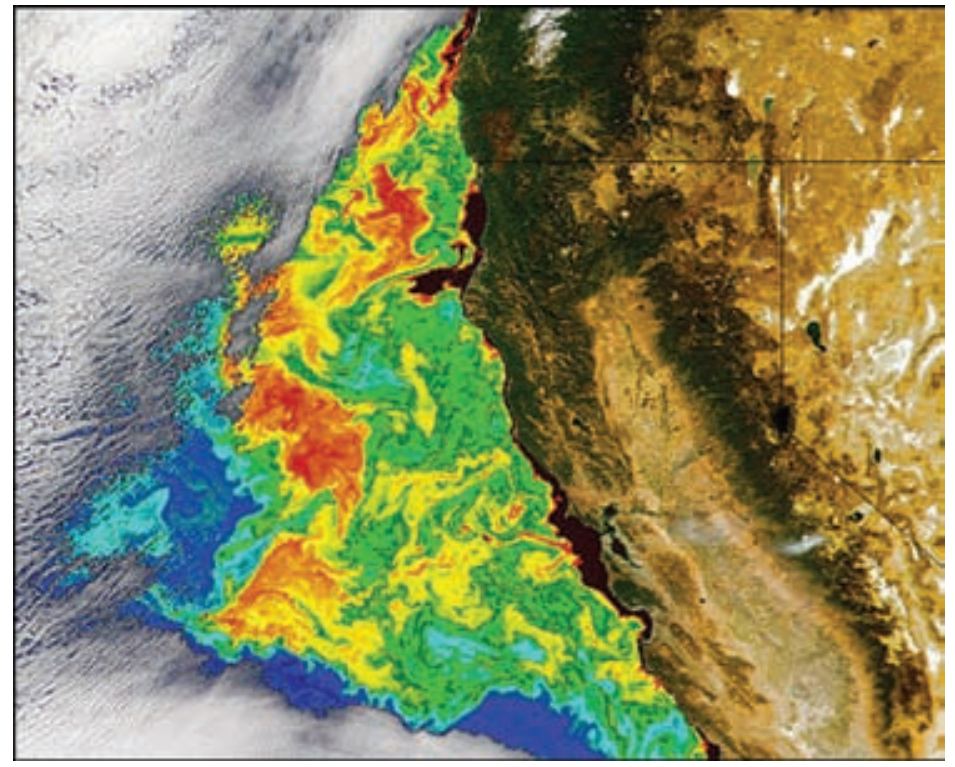

Figure 6: Chlorophyll concentration in the off-coast of California estimated using the SeaWiFS and MODIS sensors. Bright reds indicate high concentrations and blues indicate low concentrations.

Source: http://science.nasa.gov/earth-science/oceanography/living-ocean/remote-sensing/

moisture, which is highly advantageous in hydrologic analyses.

\subsection{Water quality}

Water quality is the general term used to describe the physical, chemical, thermal and biological characteristics of water e.g., temperature, chlorophyll content, turbidity, clarity, Total Suspended Solids (TSS), nutrients, Colored Dissolved Organic Matter (CDOM), tripton, dissolved oxygen, $\mathrm{pH}$, Biological Oxygen Demand (BOD), Chemical Oxygen Demand (COD), total organic carbon, and bacteria content. Conventional method for monitoring the water quality parameters by taking in-situ measurement and conducting laboratory analysis is very elaborate, and time consuming. The method is generally less capable of providing temporal and spatial coverage necessary for the accurate assessment in large water bodies. Application of the remote sensing techniques, due to their capability to provide better spatial and temporal sampling frequencies, are gaining importance in the water quality assessment. Figure 6 shows the chlorophyll concentration in the off-coast of California using observation from the SeaWiFS and MODIS sensors. 
In remote sensing, water quality parameters are estimated by measuring changes in the optical properties of water caused by the presence of the contaminants. ${ }^{57,3}$ Therefore, optical remote sensing has been commonly used for estimating the water quality parameters. Water quality parameters that have been successfully extracted using remote sensing techniques include chlorophyll content, turbidity, secchi depth, total suspended solids, colored dissolved organic matter and tripton. In addition, thermal remote sensing methods have been widely used to estimate the water surface temperature in lakes and estuaries. Table 3 gives a brief summary of some of the works wherein the remote sensing data has been used for estimating the water quality parameters.

In remote sensing, optimum wavelength to be used to measure the water quality parameter depends on the substance that is measured. Based on several in-situ analyses, the VIS and NIR portions of the EMR spectrum with wavelengths ranging from 0.7 to $0.8 \mu \mathrm{m}$ were found to be the most useful bands for monitoring suspended sediments in water. ${ }^{66,67}$ Optical properties of the water measured using remote sensing techniques are then converted into the water quality indices by using empirical relationships, radiative transfer functions or physical models.

In the empirical models, relationship between the water quality parameters and the spectral records are used to estimate the parameters. ${ }^{68}$ General forms of such relationships are the following: ${ }^{1}$

$Y=A+B X \quad$ or $\quad Y=A B^{x}$

where $Y$ is the measurement obtained using the remote sensors and $X$ is the water quality parameter of interest, and $A$ and $B$ are the empirical factors.

For example Harding et al. ${ }^{69}$ used the following empirical relationship to estimate chlorophyll content in the Chesapeake Bay.

$\log _{10}[$ Chlorophyll $]=A+B\left(-\log _{10} G\right)$

$G=\frac{\left(R_{2}\right)^{2}}{R_{1} \cdot R_{3}}$

where $A$ and $B$ are empirical constant derive from in situ measurements, $R_{1}, R_{2}$ and $R_{3}$ are the radiances at $460 \mathrm{~nm}, 490 \mathrm{~nm}$ and $520 \mathrm{~nm}$, respectively.

The empirical models, though simple and efficient, lack a general applicability. The relationship derived for one area and one condition may not be applicable for other areas or conditions. A more general approach can be the use of analytical models that employ simplified solutions of the Radiative Transfer Equations (RTEs) to relate the water surface reflectance $\left(R_{r s}\right)$ to the controlling physical factors. Such analytical algorithms require calibration of the empirical coefficients. ${ }^{63,70}$ For example, Volpe et al. ${ }^{70}$ used a RTE to relate the reflectance measured using remote sensing techniques to the physical parameters, so as to determine the Suspended Particulate Matter (SPM) concentration in lagoon/estuarine waters. The model was represented using the following equations: ${ }^{71,72}$

$$
\begin{aligned}
& R_{r s}=\frac{0.5 r_{r s}}{1-1.5 r_{r s}} \\
& r_{r s}=r_{r s}^{d p}\left[1-e^{-\left(K_{d}+K_{u}^{C}\right) H}\right]+\frac{\rho_{b}}{\pi} e^{-\left(K_{d}+K_{u}^{B}\right) H}
\end{aligned}
$$

where

$$
\begin{aligned}
r_{r s}= & \text { subsurface remote sensing reflectance } \\
r_{r s}^{d p}= & r_{r s} \text { for optically deep waters }=(0.084+ \\
& 0.17 u) u \\
u= & b_{b} /\left(a+b_{b}\right), \text { where } b_{b} \text { is the backscatter- } \\
& \text { ing coefficient and } a \text { is the absorption } \\
& \text { coefficient } \\
K_{d}= & \text { Vertically averaged diffuse attenuation } \\
& \text { coefficient for downwelling irradiance }= \\
& D_{d} \alpha \\
D_{d}= & 1 / \cos \left(\theta_{w}\right), \text { where } \theta_{w} \text { is the subsurface solar } \\
& \text { zenith angle } \\
K_{u}^{C}= & \text { Vertically averaged diffuse attenuation } \\
& \text { coefficient for upwelling radiance from } \\
& \text { water-column scattering }=D_{u}^{C} \alpha \\
K_{u}^{B}= & \text { Vertically averaged diffuse attenuation } \\
& \text { coefficient for upwelling radiance from } \\
& \text { water-column scattering }=D_{u}^{B} \alpha \\
\alpha= & a+b_{b} \\
D_{u}^{C}= & 1.03(1+2.4 u)^{0.5} \\
D_{u}^{B}= & 1.03(1+5.4 u)^{0.5} \\
\rho_{b}= & \text { Bottom albedo } \\
H= & \text { water depth }
\end{aligned}
$$

The backscattering and the absorption coefficients were determined by calibration. The RTE algorithms help to get a better insight about the processes and hence are applicable to a wider range of conditions compared to the empirical models. ${ }^{70}$

Remote sensing of the water quality parameter in the earlier days employed fine resolution optical images from the satellites e.g., Landsat TM. ${ }^{60}$ However, poor temporal coverage of the images (once in 16 days) was a major limitation in such studies. With the development of new satellites and sensors, the spatial, temporal and radiometric resolutions have improved significantly. Using 


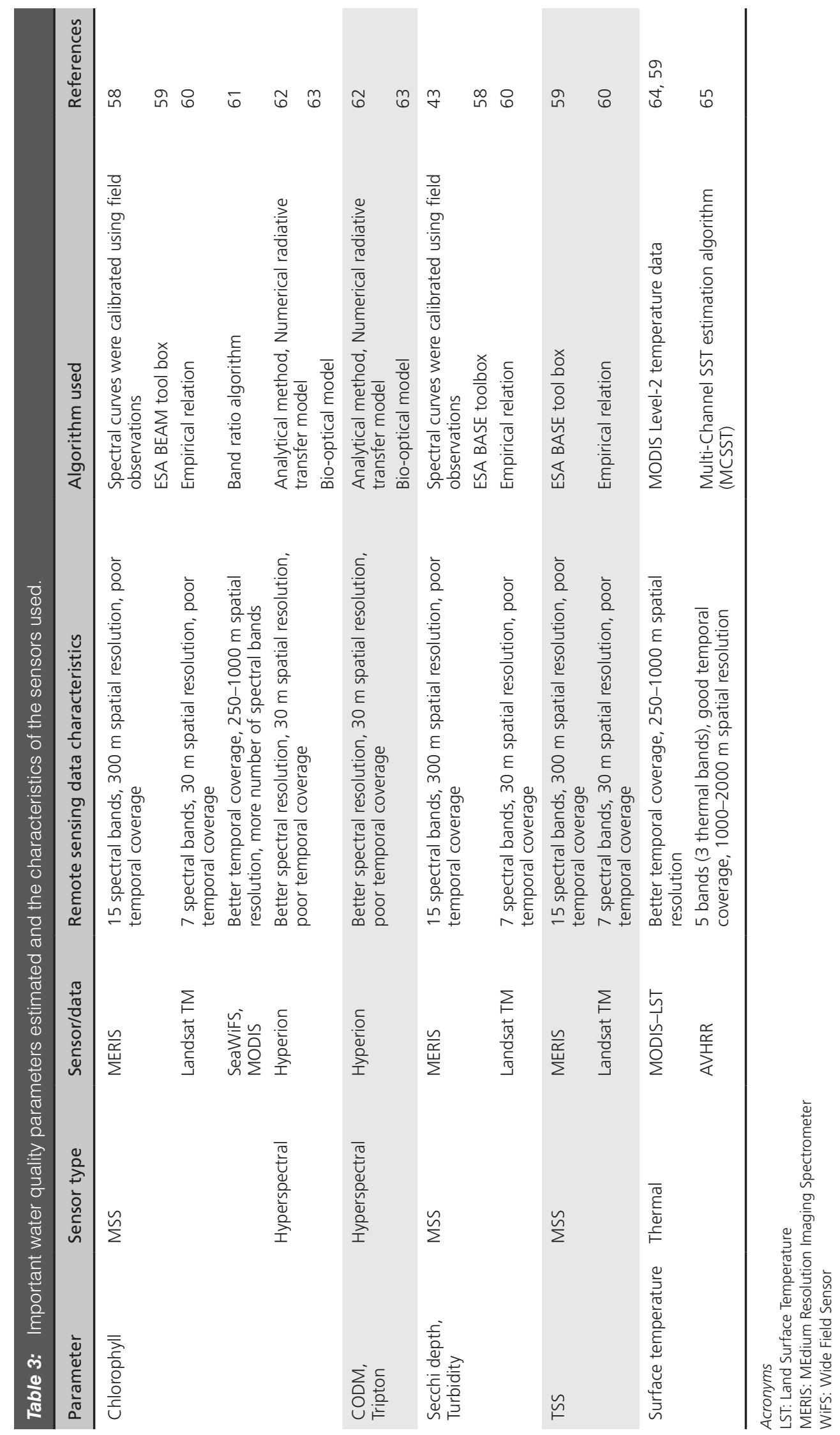


sensors such as MODIS (with 36 spectral bands) and MERIS (with 15 spectral bands) better accuracy in the estimation of water quality parameters has been achieved. ${ }^{73,74}$

A recent development in the remote sensing application in water quality monitoring is the use of hyper-spectral images in monitoring the water quality parameters. The large number of narrow spectral bands used in the hyper-spectral sensors help in improved detection of the contaminants and the organic matters present in water. Use of hyper-spectral images to monitor the tropic status of lakes and estuaries, ${ }^{58,75,76}$ assessment of total suspended matter and chlorophyll content in the surface water ${ }^{77-79}$ and bathymetric surveys ${ }^{80}$ are a few examples.

\subsection{Land cover classification}

Land cover classification using multispectral remote sensing data is one of the earliest, and well established remote sensing applications in water resources studies. ${ }^{17}$ Detailed land cover classification has been used to extract the hydrologic parameters that are important in distributed hydrologic modeling. ${ }^{81}$ Remote sensing also finds application in hydrologic analysis to study the impact of changing land use pattern (e.g., forest coverage, urbanization, agricultural pattern etc.) on various hydrologic responses of the catchment.

Land use/land cover classification from the satellite imageries is based on the difference in the spectral reflectance of different land use classes in different bands of the EMR spectrum. A large number of earlier studies show the hydrologic application of the land use/land cover maps generated from the IRS LISS- $3^{82,83}$ and Landsat MSS and $\mathrm{TM}^{+84,85}$ imageries. Spatial resolution of the land use/land cover maps generated from these imageries ranges from $23-30 \mathrm{~m}$. With the availability of finer resolution satellite images (e.g., IKONOS, and Quickbird), now it is possible to generate the land use land cover maps of less than $1 \mathrm{~m}$ spatial accuracy.

The use of hyper-spectral imageries helps to achieve further improvement in the land use/land cover classification. In hyperspectral remote sensing, the spectral reflectance values recorded in the narrow contiguous bands are used to generate the spectral reflectance curves for each pixel. Using these spectral reflectance curves which are unique for different land use classes, it is now possible to achieve differentiation of classes (e.g., identification of crop types) that are difficult from the multi-spectral images ${ }^{86}$

With the help of satellite remote sensing, land use land cover maps at near global scale are available today for hydrological applications. European Space Agency (ESA) has released a global land cover map of $300 \mathrm{~m}$ resolution, with 22 land cover classes at 73\% accuracy (Fig. 7).

\subsection{Evapotranspiration}

Evapotranspiration (ET) represents the water and energy flux between the land surface and the lower atmosphere. ET fluxes are controlled by the feedback mechanism between the atmosphere and the land surface, soil and vegetation characteristics, and the hydro-meteorological conditions. There are no direct methods available to estimate the actual ET by means of remote sensing techniques. Remote sensing application in the ET estimation is limited to the estimation of the surface conditions like albedo, soil moisture, vegetation characteristics like Normalized Differential Vegetation Index (NDVI) and Leaf area Index (LAI), and the surface temperature. The data obtained from remote sensing are used in different models to simulate the actual ET.

Couralt et al. ${ }^{87}$ grouped the remote sensing data-based ET models into four different classes: empirical direct methods, residual methods of the energy budget, deterministic methods and the vegetation index methods. Empirical direct methods use the empirical equations to relate the difference in the surface air temperature to the ET. For example, Jackson et al. ${ }^{88}$ used a relationship to relate the difference in the canopy and air temperatures to the ET as given in the equation.

$\mathrm{ET}=0.438-0.064\left(T_{c}-T_{a}\right)$

where $T_{c}$ is the plant canopy temperature, and $T_{a}$ the air temperature $0.15 \mathrm{~m}$ above the soil.

The surface air temperature measured using the remote sensing technique is used as the input to the empirical models to determine the ET.

Residual methods of the energy budget use both empirical and physical parameterization. The popular Surface Energy Balance algorithm for Land (SEBAL) is an example. ${ }^{89}$ The model requires incoming radiation, surface temperature, NDVI (Normalized Differential Vegetation Index) and albedo, which are estimated from the remote sensing data. FAO-56 method, ${ }^{90}$ based on the Penmann-Monteith method, is another commonly used model. It is used to estimate reference ET (ET from a hypothetical reference grass under optimal soil moisture condition) by using the solar radiation, temperature, wind speed and relative humidity data. Actual crop ET is estimated from the reference ET, with the help of additional 


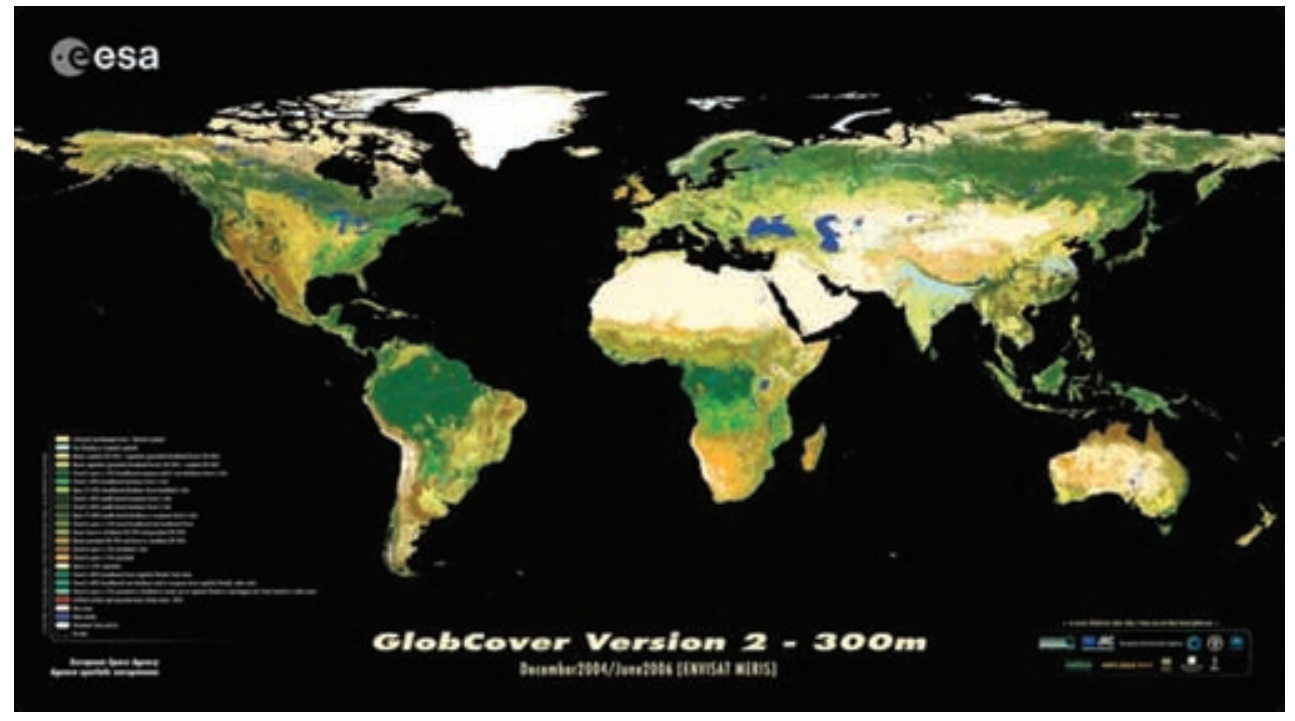

Figure 7: Global $300 \mathrm{~m}$ land cover classification from the European Space Agency. Source: http://www.esa.int/Our_Activities/Observing_the_Earth/ESA_global_land_cover_map_available_online

information like crop coefficients and soil moisture condition. Remote sensing data can be used to retrieve such additional information at finer spatial and temporal resolution.

Deterministic models simulate the physical process between the soil, vegetation and atmosphere making use of remote sensing data such as Leaf Area Index (LAI) and soil moisture. SVAT (Soil-Vegetation-Atmosphere-Transfer) model is an example. ${ }^{91}$ Vegetation index methods use the ground observation of the potential or reference ET. Actual ET is estimated from the reference ET by using the crop coefficients obtained from the remote sensing data. ${ }^{92,93}$

Optical remote sensing using the VIS and NIR bands have been commonly used to estimate the input data required for the ET estimation algorithms. As a part of the NASA/EOS project to estimate global terrestrial ET from land surface by using satellite remote sensing data, MODIS Global Terrestrial Evapotranspiration Project (MOD16) provides global ET data sets at regular grids of 1 sq.km for the land surfaces at 8-day, monthly and annual intervals for the period 2000-2010. Three components of the ET viz., evaporation from wet soil (related to the albedo), evaporation from the rainwater intercepted by the canopy (related to the LAI) and the transpiration through the stomata on plant leaves and stems (depends on LAI, pressure deficit, and daily minimum air temperature) are considered in this. The project used remote sensing data from the MODIS sensor to estimate the land cover, LAI and albedo. This information was clubbed with the meteorological data viz., air pressure, humidity, radiation to calculate the ET by using the algorithm proposed by $\mathrm{Mu}$ et al..$^{94}$ Figure 8 shows the flowchart showing the methodology adopted for the MOD16 global ET product. In this, TIR bands are used for the remote sensing of the surface temperature, which is an essential input data for the estimation of ET, whereas the VIS and NIR bands are used for deriving the vegetation indices such as NDVI.

Finer spatial resolution of the VIS and NIR bands makes the field level estimation of the vegetation indices possible. Nevertheless, spatial resolution of the TIR bands are relatively less ( 1 to $4 \mathrm{~km}$ ) compared to the VIS and NIR bands, making the field level temperature estimation not viable. A comparison of the spatial and temporal resolution of the some of the commonly used sensors for the ET estimation is provided by Courault et al..$^{87}$ Kustas et al. ${ }^{95}$ proposed a disaggregation methodology to estimate sub-pixel level temperature data using a relationship between the radiometric temperature and the vegetation indices. This is a promising approach for the estimation of the field level ET from the remote sensing data.

\section{Applications of Remote Sensing in Water Resources}

Estimation of the hydro-meteorological state variables and delineation of the surface water bodies by using the remote sensing techniques find application in the areas of rainfall-runoff 

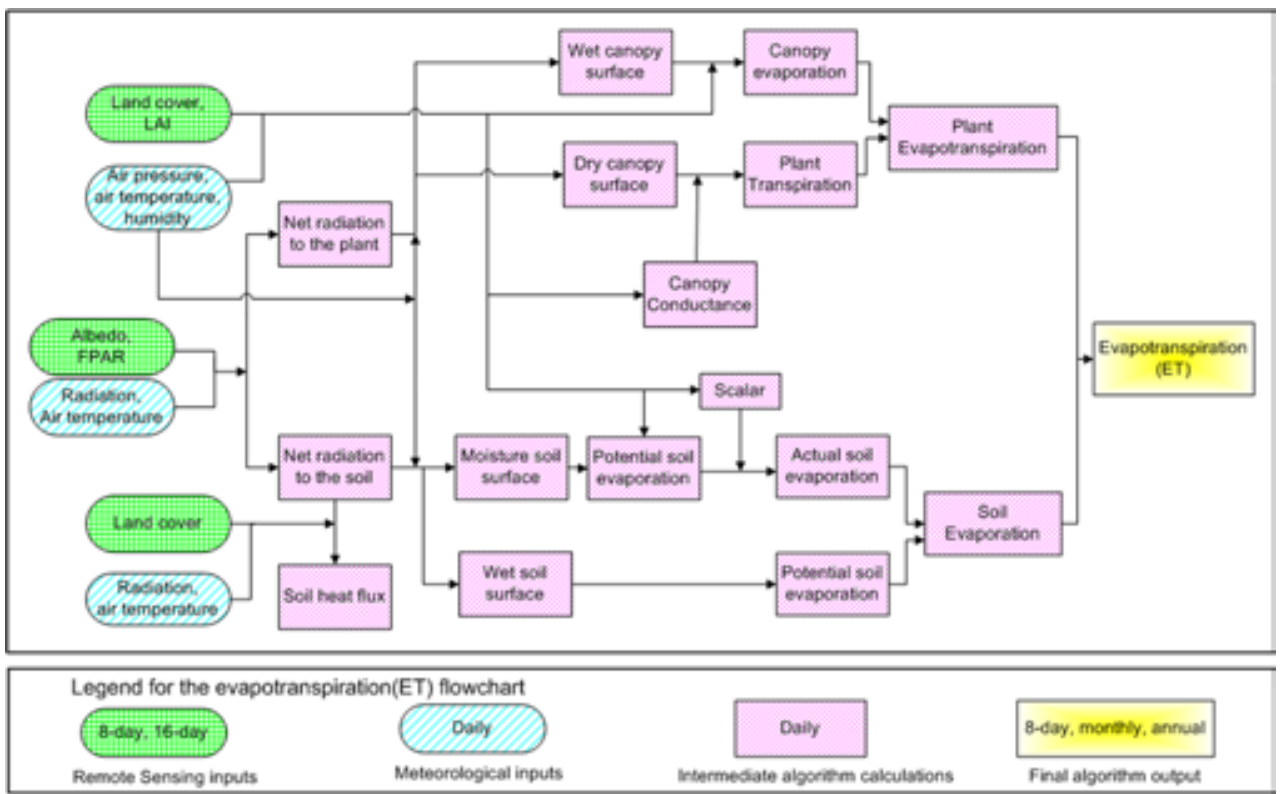

Figure 8: Schematic representation of the MOD16 ET algorithm ${ }^{94}$ (courtesy: http://www.ntsg.umt.edu/ project/mod16).

modeling, irrigation management, flood forecasting, drought monitoring, water harvesting and watershed planning and management. Some of these applications are briefly mentioned in the following subsections.

\subsection{Rainfall-runoff studies}

The most common application of the remote sensing techniques in the rainfall-runoff studies is the estimation of the spatially distributed hydrometeorological state variables that are required for the modeling, e.g., rainfall, temperature, ET, soil moisture, surface characteristics and land use land cover classes. Remote sensing methods used for the estimation of these parameters are described in the previous sections. Advantage of the remote sensing techniques over the conventional methods is the high spatial resolution and areal coverage that can be achieved relatively easily. ${ }^{96}$

While selecting the hydrological model for integration with the remote sensing data, spatial resolution of the hydrological model structure and the input data must be comparable. Papadakis et al. ${ }^{97}$ carried out a detailed sensitivity analysis in the river basins in West Africa to find the spatial, temporal and spectral resolution required for the hydrologic modeling. Fine resolution data was found to be relevant only if the hydrologic modeling uses spatially distributed information of the all the relevant input parameters sufficient enough to capture the spatial heterogeneity, and when the highly dynamic processes were monitored. ${ }^{12}$
Hydrologic models that incorporate the remote sensing information include regression models, conceptual model, and distributed model. One of the widely used conceptual model is the SCS-CN model ${ }^{98}$ which compute the surface runoff using the parameter Curve Number $(\mathrm{CN})$. The $\mathrm{CN}$ is related to the soil and land use characteristics. Application of the remote sensing data allowed a better representation of the land use, and thus a more reliable estimation of the relevant $\mathrm{CN} .{ }^{99}$ Use of remote sensing data also helps in updating the land use changes in the hydrologic models, particularly in the areas where the land use pattern is highly dynamic, causing significant variation in the hydrologic processes. Another commonly used model is the Variable Infiltration Capacity (VIC) model. ${ }^{100} \mathrm{VIC}$ model requires information about the atmospheric forcing, surface meteorology and surface characteristics, which can be derived from the remote sensing data. ${ }^{100}$

Remote sensing application also helps to improve the hydrologic modeling by providing vital information about the soil moisture content $t^{101,102}$ and ET rates. ${ }^{103,104}$ Use of radar images for estimating the Saturation Potential Index (SPI), an index used to represent the saturation potential of an area, is another application of the remote sensing in runoff modeling. Gineste et al. ${ }^{105}$ used the SPI derived from remote sensing, together with the topographic index in the TOPMODEL to improve the runoff simulation.

With the advancement of technology, today it is possible to estimate the stream discharge by 
measuring the channel cross section and slopes from remote sensing platforms. Durand et al. ${ }^{106}$ used radar images from the Surface Water and Ocean Topography (SWOT) mission to extract the water surface elevation, which was further used in a depth and discharge estimation algorithm to calculate the channel flow depth and the discharge in the Ohio River. The error in the instantaneous discharge measurement was found to be less than $25 \%$ in $86 \%$ of the observations. In another study by Bjerklie et al., ${ }^{107}$ surface velocity and width information obtained using the C-band radar image from the Jet Propulsion Laboratory's (JPL's) AirSAR was used to estimate the discharge in the Missouri River with $72 \%$ accuracy.

\subsection{Drought monitoring}

Monitoring of drought events and quantification of impact of the drought are important to place appropriate mitigation strategies. The advantage of remote sensing application in drought monitoring is the large spatial and temporal frequency of the observation, which leads to a better understanding of the spatial extent of drought, and its duration. Satellite remote sensing techniques can thus help to detect the onset of drought, its duration and magnitude.

Remote sensing methods are now being widely used for large scale drought monitoring studies, particularly for monitoring agricultural drought. Agricultural drought monitoring from the remote sensing platform is generally based on the measurement of the vegetation condition (e.g. NDVI) and/or the soil moisture condition, ${ }^{14}$ using which various drought monitoring indices are derived, at a spatial resolution of the imagery. A map of the drought monitoring index can be used to understand the spatial variation in the drought intensity. Figure 9 shows a sample weekly Palmer Drought Index map, derived using the satellite remote sensing data, for the United States published by NOAA.

Remote sensing methods of drought monitoring can also be used to predict the crop yield in advance. ${ }^{108}$ A concise review of the remote sensing applications in drought monitoring has been provided by McVicar and Jupp. ${ }^{14}$ Remote sensing data from the satellites/sensors viz., AVHRR, ${ }^{109,110}$ Landsat TM and ETM $^{+}, 111,112$ IRS LISS- 1 and LISS-2, ${ }^{113,114}$ SPOT $^{115}$ and MODIS ${ }^{116,117}$ have been widely used in drought monitoring. Some of the operational drought monitoring and early warning systems using remote sensing application are the following: Drought Monitor of USA using NOAA-AVHRR data, Global Information and Early Warning System (GIEWS) and Advanced Real Time Environmental Monitoring Information System (ARTEMIS) of FAO using Meteosat and SPOT_-VGT data, and Drought assessment in South west Asia using MODIS data by the International Water Management Institute.

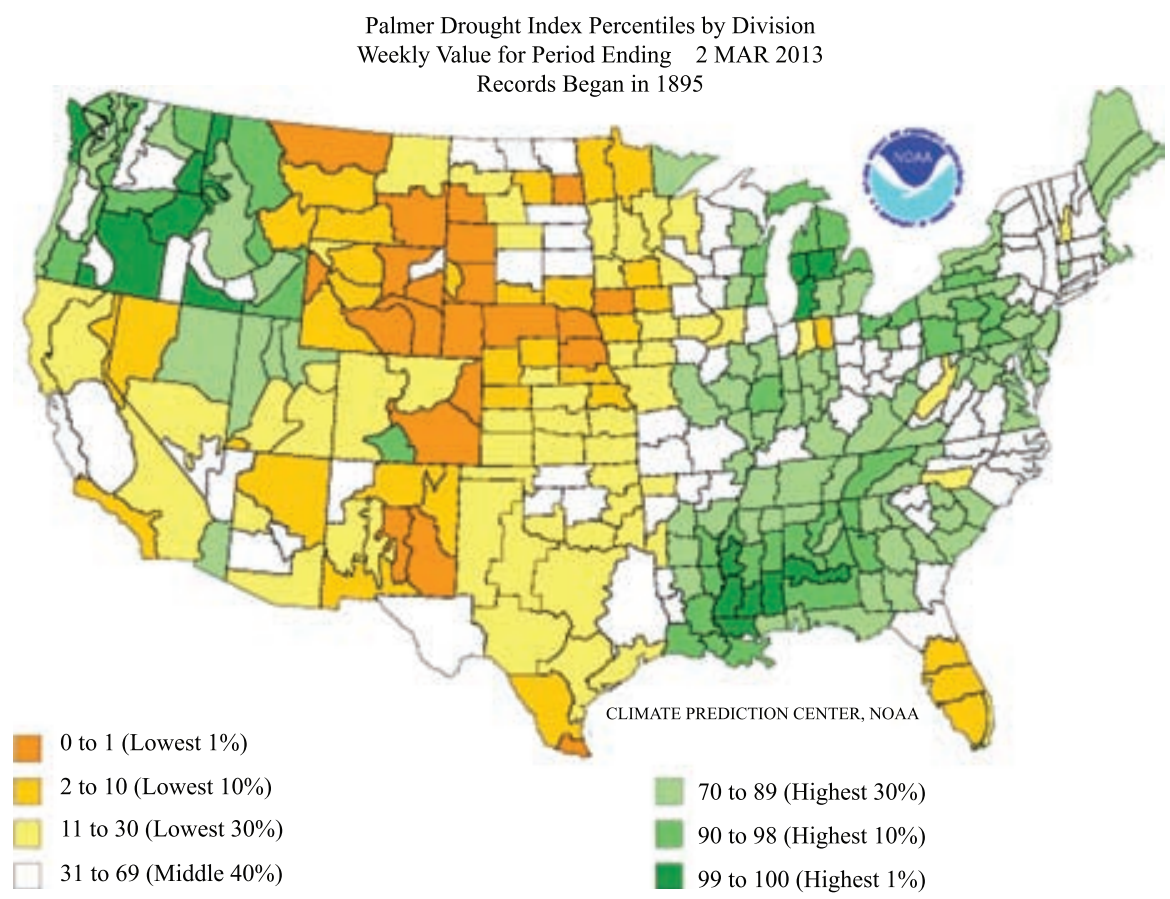

Figure 9: Weekly Palmer Drought Index map for the United States. 
The National Agricultural Drought Assessment and Monitoring System (NADAMS) project of India is another very good example of effective drought monitoring and early warning system using satellite remote sensing. The NADAMS project uses moderate resolution data from Advanced Wide Field Sensor (AWiFS) of Resourcesat 1 (IRS P6), and WiFS of IRS 1C and 1D for detailed assessment of agricultural drought at district and sub-district level in Andhra Pradesh, Karnataka, Haryana and Maharashtra.

\subsection{Flood forecasting}

The poor weather condition generally associated with the floods, and the poor accessibility due to the flooded water makes the ground and aerial assessment of the flood inundated areas a difficult task. Application of satellite remote sensing helps to overcome these limitations. Through the selection of appropriate sensors and platforms, remote sensing can provide accurate and timely estimation of the flood inundation, flood damage and flood-prone areas. Table 4 provides a list of satellites commonly used for flood monitoring and their characteristics.

Satellite remote sensing uses both IR and microwave bands for delineating the flooded areas. The algorithms used for delineating the flooded areas are based on the absorption of the IR bands by water, giving darker tones for the flooded areas in the resulted imagery. ${ }^{130}$ Images from Landsat TM and $\mathrm{ETM}^{+}$, SPOT and IRS LISS-3 and LISS-4 are largely used in the flood analysis. Satellite images acquired in different spectral bands during, before and after a flood event can provide valuable information about the extent of area inundated during the progress or recession of the flood. ${ }^{131}$ For example, Figure 10 (from Bhatt et al.) ${ }^{132}$ shows the IRS P6 LISS-3 and LISS-4 images of the Bihar floods which occurred in August 2008 due to the breeching of the Kosi River embankment. The images taken shortly after the flood (Fig. 10a) shows the extent of inundated areas, compared to the image taken 8 months after the flood (Fig. 10c).

Sensors operational in the optical region of the EMR spectrum generally provides very fine spatial resolution. Nevertheless, major limitations of the optical remote sensing (e.g., Landsat and IRS satellites) in flood monitoring are the poor penetration capacity through cloud cover and poor temporal coverage. Revisit periods of these satellites typically varies from 14 to 18 days. Even though the AVHRR sensors onboard NOAA satellites provide daily images, spatial resolution of the images is very coarse. In addition, operational difficulty in the poor weather condition is also a major limitation.

Microwave, particularly radar remote sensing, is advantageous over the optical remote sensing as the radar signals can penetrate through the cloud cover and can extract the ground information even in bad weather conditions. Taking the benefits of radar imaging and optical remote sensing, in many studies, a combination of both has been used for flood monitoring. $13,128,133,134$

Digital Elevation Model (DEM) derived using the remote sensing methods (e.g. SRTM and ASTER GDEM) also finds application in flood warning. When a hydrologic model is used to predict the flood volume, elevation information can be obtained from the DEM, using which the areas likely to be inundated by the projected flood volume can be identified. ${ }^{135}$ With finer and more accurate vertical accuracy of the DEM, better analyses can be undertaken using it. With the technological development, it is feasible to generate very fine resolution DEM using the Light Detection and Ranging (LiDAR) data, and this can significantly improve the flood warning services.

Table 4: Some of the important satellites and sensors used for flood monitoring.

\begin{tabular}{llll}
\hline Sensor & Satellite & Characteristics & References \\
\hline Landsat TM & Landsat 4-5 & $\begin{array}{l}30 \text { m spatial resolution, Temporal coverage: } \\
\text { once in 16 days, Poor cloud penetration }\end{array}$ & 118,119 \\
IRS LISS-3 & IRS 1C/1D & $\begin{array}{l}23 \text { m spatial resolution, Temporal coverage: } \\
\text { once in 24 days, Poor cloud penetration }\end{array}$ & 120,121 \\
SPOT & SPOT & $\begin{array}{l}\text { 8-20 m spatial resolution, Temporal coverage: } \\
\text { once in 5 days, Poor cloud penetration }\end{array}$ & 122 \\
AVHRR & NOAA & $\begin{array}{l}\text { 1.1 km spatial resolution, Temporal coverage: } \\
\text { Daily coverage, Poor cloud penetration }\end{array}$ & 123,124 \\
MODIS & Terra & $\begin{array}{l}250 \text { m spatial resolution, Temporal coverage: } \\
\text { Daily coverage, Poor cloud penetration }\end{array}$ & 125,126 \\
SAR & Envisat, ERS 1, 2, & $\begin{array}{l}20-30 \text { m spatial resolution, Temporal } \\
\text { coverage: } 1-3 \text { days, Good cloud penetration }\end{array}$ & $127-129$ \\
\hline & Radarsat & &
\end{tabular}




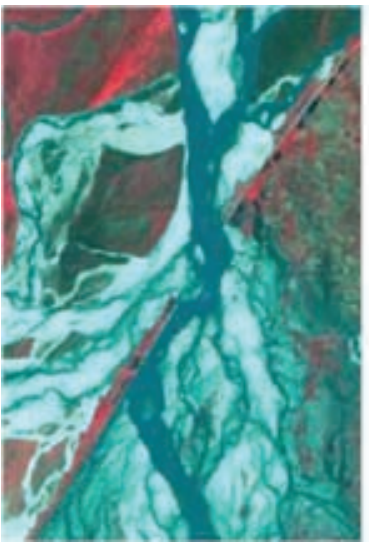

(a)

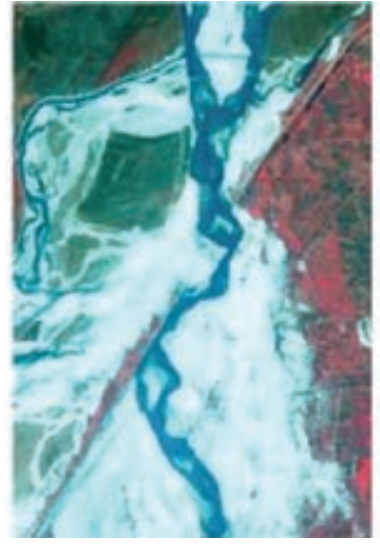

(b)

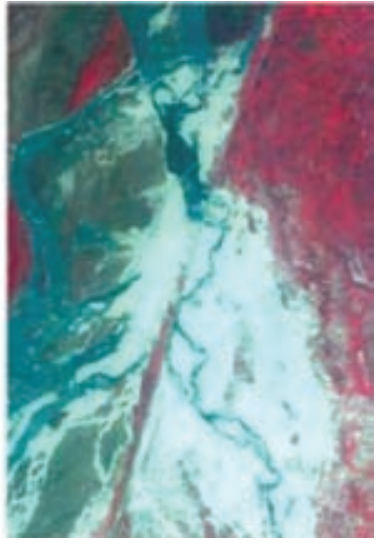

(c)

Figure 10: Images of Kosi River breach occurred in August 2008 (a) IRS P6 LISS-3 image on 25th Oct 2008 (b) IRS P6 LISS-4 image on 5th Jan 2009 (c) IRS P6 LISS-4 image on 20th April 2009.

Source: Bhatt et al. ${ }^{132}$

In India, disaster management using satellite remote sensing has been operational for more than two decades ${ }^{136}$ by the National Remote Sensing Agency (NRSA), and the Indian Space Research Organization (ISRO). In case of a flood event, maps showing the flood affected areas and the flood damage statistics are released near real-time. The system uses the near real-time meteorological data from KALPANA-1 satellite and the rainfall data from the TRMM to generate the flood warning. Also, satellite imageries (from IRS satellites) are collected at different intervals to detect the changes in the inundated areas. This information is integrated with the other data like land cover maps, basin utility maps, administrative boundaries etc., to analyze the flood damage.

\subsection{Irrigation management}

Remote sensing application in irrigation management includes crop classification, irrigated area mapping, performance evaluation of the irrigation systems, and irrigation advisory services. Crop classification using the satellite remote sensing images is one of the most common applications of remote sensing in agriculture and irrigation management. Multiple images corresponding to various cropping periods are generally used for this purpose. The spectral reflectance values observed in various bands of the images are related to specific crops with the help of ground truth data. ${ }^{137,138}$

Identification of the irrigated area from the satellite images is based on the assessment of the crop health and the soil moisture condition. ${ }^{139-141}$ For example, Biggs et al. ${ }^{142}$ used data from the MODIS sensor to map the irrigated areas in the
Krishna basin in India. Time series of the NDVI were generated from the MODIS images and used to assess the crop health, and to group the crops into various random classes. Ground truth and the statistical information were then used to identify the irrigated and non-irrigated areas from these random classes.

In irrigation management studies satellite remote sensing data are used to capture the spatial and temporal variations in the crop ET and soil moisture. This information is clubbed with various models to simulate the crop production and to estimate the irrigation efficiency. Performance of the irrigation system is generally evaluated using indices such as relative water supply and relative irrigation supply. ${ }^{143}$ Bastiaanssen ${ }^{144}$ has listed a set of irrigation performance indices derived with the help of the remote sensing data. Soil-Adjusted Vegetation Index (SAVI), NDVI, Transformed Vegetation Index (TVI), Normalized Difference Wetness Index (NDWI), Green Vegetation Index (GVI) are a few of them. Several studies conducted in the past show the potential of the remote sensing data from Landsat TM, MODIS, IRS-LISS and WiFS sensors in the evaluation of the irrigation system performance. ${ }^{143,145-147}$

Irrigation Advisory Services (IAS) are the services used to help the farmers to improve the irrigation efficiency and to optimize the agricultural production from the use of irrigation water. ${ }^{16}$ Irrigation scheduling information based on the crop type, agro-meteorology and the soil moisture availability, is an example. ${ }^{90}$ The conventional methods of IAS using in-situ measurement from the field were less capable of providing the information at a spatial and temporal resolution to 
adequately represent the dynamics of the problem. The use of remote sensing to capture the dynamic crop characteristics has drastically improved the capability of the IAS systems. Remote sensing application in IAS system includes the extraction of the spatial variation in the crop characteristics such as cropping pattern, estimation of the crop ET and crop indices such as NDVI, and the regular update of the information to capture the temporal variation. ${ }^{16}$ With the help of remote sensing data, the spatio-temporal variation in the irrigation water demand is better captured, resulting in a more efficient irrigation scheduling. DEMETER (DEMonstration of Earth observation Technologies in Routine irrigation advisory services) is a very good example of the use of satellite remote sensing in IAS. DEMETER has a few pilot scale implementations in Spain, Italy and Portugal. ${ }^{16,148}$

\subsection{Rain water harvesting}

The techniques of rainwater harvesting are highly location specific ${ }^{149}$ and need extensive field analysis. Identification of the rainwater harvesting potential of the area, and suitable locations for the water harvesting structures are the essential prerequisites for the successful implementation of any rainwater harvesting projects. Remote sensing techniques, due to their wide range of capabilities for identifying the geomorphologic and surface characteristics, is advantageous in analyzing the water harvesting potentials and to identify the suitable sites for the water harvesting structures. ${ }^{149-152}$

In a study by Jasrotia et al., ${ }^{149}$ satellite images from IRS 1D LISS-3 were used to extract the land use land cover map. This information was integrated with the other data like soil, slope, and drainage maps to identify the suitability of various water harvesting sites in Devak-Rui watershed in Jammu District, in India. In another study, Kumar et al. ${ }^{150}$ used images from IRS LISS-2 sensors to prepare thematic layers of land use/land cover, geomorphology, and lineaments. These layers, along with the geology and drainage information were used to identify the potential sites for rainwater harvesting in the Bakhar watershed in Uttar Pradesh, India. Results of these studies show the advantages of the remote sensing data in estimating the runoff harvesting potential and in identifying suitable locations for the water harvesting structures.

\subsection{Watershed planning and management}

Remote sensing through air-borne and spaceborne sensors, can be effectively used for watershed characterization and watershed priority assessment. Application of remote sensing has multiple dimensions in the watershed management like water resource mapping, land cover classification, estimation of water yield, soil erosion, land prioritization and water harvesting, as mentioned in the previous sections. Mapping of saline and water logged areas is another application of the remote sensing data in watershed management.

Remote sensing data have been clubbed with the hydrological models to simulate the impacts of human interventions (e.g. agricultural practices, reservoirs, water harvesting) and external influences (e.g. climate change) on the water balance. Rainfall and hydro-meteorological variables, watershed topography, watershed area, size and boundary, surface characteristics, drainage pattern, land use/land cover, soil moisture condition, ET, water quality parameters etc. are a few of the essential information that remote sensing can supply for the hydrologic monitoring of the watershed. Data products from the Landsat MSS, $\mathrm{ETM}^{+}$, IRS LISS-3, IKONOS, AMSR-E, MODIS, and AVHRR sensors have been widely applied in watershed management studies at various levels as mentioned in the previous sections. In addition, active microwave remote sensing using SAR are also largely used in watershed studies (e.g., SRTM DEM, radar for rainfall estimation, ASCAT soil moisture data). With the technological advancement, currently hyper-spectral sensors are also used to achieve high resolution crop classification and water quality estimation in watershed management studies.

Use of IRS LISS-2 and LISS-3 images for watershed characterization and to study the suitability of soil conservation measures in different terrain and land use conditions, ${ }^{153}$ use of Landsat TM images in a watershed prioritization study to identify the potential for soil and water conservation, ${ }^{154}$ prioritization of sub-watersheds based on the satellite remote sensing (IRS LISS-3) derived river morphometric parameters, ${ }^{155}$ are some good case studies of the remote sensing application in watershed management.

\subsection{Groundwater studies}

Another important application of remote sensing is in groundwater assessment and management. Comprehensive reviews of the remote sensing application in the groundwater studies have been provided by Meijerink ${ }^{156}$ and Brunner et al. ${ }^{157}$ Remote sensing application in the groundwater studies are generally classified into three broad areas: estimation of the geomorphologic parameters essential for the groundwater modeling, 
estimation of the groundwater storage, and estimation of the groundwater potential.

Extraction of geological and surface information such as presence of faults, dykes and lineaments, changes in the lithology, terrain characteristics, using different types of sensors (e.g., Landsat TM, IRS LISS) have been some of the common applications of remote sensing in groundwater studies. Remote sensing techniques can also be used to extract the water levels in the lakes and rivers, which is an essential input for the groundwater modeling. Terrain height, another important parameter, particularly in the case of phreatic aquifer, can also be derived from the remote sensing techniques. With the use of modern techniques like radar interferometry and Lidar altimetry, fine resolution DEM is now available, which can significantly improve the groundwater simulations. Remote sensing data, when combined with the ground-based observations and numerical modeling have been found to have many applications in the groundwater studies. ${ }^{158}$

Since the optical and microwave signals used in satellite remote sensing cannot penetrate beyond the top soil layer, ${ }^{159}$ direct estimation of the groundwater storage is not possible using these bands. Current approaches to estimate the groundwater storage levels are based on the Terrestrial Water Storage (TWS) estimated using the data from the Gravity Recovery and Climate Experiment (GRACE) satellites of NASA, along with the ground-based observations. GRACE satellites are used to measure the temporal variation in the gravity field, which is used to estimate the changes in the TWS. ${ }^{159}$ Yeh et al. ${ }^{160}$ used the monthly TWS data from the GRACE together with the in-situ measurements of soil moisture to estimate the regional groundwater storage in Illinois. The algorithm used to retrieve the groundwater storage from TWS considered the change in the TWS as the sum of the changes in the soil moisture $(\Delta S M)$ and the groundwater storage $(\Delta G W)$ as shown in Eq. 9:

$$
\text { TWS }=\Delta S M+\Delta G W=n D \frac{d s}{d t}+S_{y} \frac{d h}{d t}
$$

where, $n$ is the soil porosity, $D$ is the root zone depth, $s$ is the soil relative saturation, $t$ is the time period, $S_{y}$ is the specific yield, $h$ is the groundwater level. Knowing the changes in the soil moisture from the field measurements, and the TWS from the GRACE data, changes in the groundwater storage can be estimated, which may be further used to estimate the groundwater level. In another study, Rodell et al. ${ }^{159}$ clubbed the soil moisture simulations from a hydrologic model with the TWS change derived from the GRACE data to show the drastic groundwater depletion in the Rajasthan, Punjab and Haryana states in India.

Groundwater potential zone identification is a typical multi-criteria evaluation problem, where the thematic layers of hydro-geological parameters are integrated in a GIS environment to identify the groundwater potential. Identification of the groundwater potential zones in the Marudaiyar Basin in India using remote sensing techniques is an example. ${ }^{161}$ Thematic maps such as lithology, landforms, lineaments and surface water were prepared from the remote sensing data and these were combined with the other information such as drainage density, slope and soil types. Logical conditions defining the groundwater potential were evaluated using these thematic layers. The groundwater potential zones thus identified were found to be in good agreement with the borewell data collected from the field. ${ }^{161}$ Potential of the remote sensing data from IRS-LISS ${ }^{162}$ and Landsat $\mathrm{TM}^{163}$ sensors in identifying the groundwater/ recharge potential areas are well documented in the literature.

\section{Concluding Remarks}

Remote sensing techniques and the data derived using the remote sensing methods have multidimensional applications in water resources studies. Applications of the remote sensing to water resources range from the simple resource mapping to the complex decision making related to the watershed characterization and prioritization.

Remote sensing data used in hydrologic studies are derived from different passive and active sensors onboard various satellites. Overview of the applications of the passive sensors operating in the VIS, IR and microwave wavelengths shows the enormous potential of the remote sensing data in improving the hydrologic studies. Recently developed hyper-spectral remote sensing technique, with its capability to achieve very fine spectral and spatial resolution, shows the scope for achieving further improvement in the hydrologic studies. The active microwave sensors, with an all-weather operational capability find potential application in the flood analysis and flood warning services.

An overview of the remote sensing applications in different fields of water resources shows the potential of the remote sensing data in water resources management. One of the major advantages of the remote sensing application is the better spatial and temporal coverage that can be easily obtained to represent the dynamic nature of the hydrological and meteorological state variables. 
Capability to obtain near-real time data from remote sensing has been found to be particularly advantageous in flood monitoring, irrigation management and drought monitoring.

\section{Acknowledgement}

This work is partially supported by Ministry of Earth Sciences, Govt. of India, through project no. MoES/ATMOS/PP-IX/09. Authors also acknowledge NASA, ESA and other organizations for the public domain images used in this paper.

\section{Received 20 March 2013}

\section{References}

1. Schmugge TJ, Kustas WP, Ritchie JC, Jackson TJ, Rango A (2002). "Remote sensing in hydrology" Adv. Water Resour., 25, pp. 1367-1385.

2. Salomonson VV, Rango A (1983). Chapter 18. In Remote Sensing in Geology, (Seigal, B.S., Gillespie, A.R. Eds.). John Wiley \& Sons, New York.

3. Lillesand TM, Kiefer RW, Chipman JW (2004). Remote Sensing and Image Interpretation, Wiley India (P.) Ltd., New Delhi.

4. Short NM (1999). Remote Sensing Tutorial—Online Handbook, Goddard Space Flight Center, NASA, USA.

5. Govender M, Chetty K, Bulcock H (2007). "A review of hyperspectral remote sensing and its application in vegetation and water resource studies" http://www.wrc.org.za/Pages /KnowledgeHub.aspx. Last accessed on 12th March, 2013.

6. Petty GW, Krajewski WF (1996). "Satellite estimation of precipitation over land” Hydrol. Sci. J., 41(4), pp. 433-451.

7. Kidd C, Levizzani V (2011). "Status of satellite precipitation retrievals" Hydrol. Earth Syst. Sci., 15, pp. 1109-1116. Doi: 10.5194/hess-15-1109-2011.

8. Kalma JD, McVicar TR, McCabe MF (2008). "Estimating land surface evaporation: A review of methods using remotely sensed surface temperature data" Surv. Geophys, 29, pp. 421-469.

9. Kondratyev KY, Pozdnyakov DV, Pettersson LH (1998). "Water quality remote sensing in the visible spectrum" Int. J. Remote Sens., 19 (5), pp. 957-979.

10. Ritchie, JC, Zimba PV, Everitt JH (2003). "Remote sensing techniques to assess water quality" Photogramm. Eng. \& Remote Sens., 69 (6), pp. 695-704.

11. Odermatt D, Gitelson A, Brando VE, Schaepman, M (2012). "Review of constituent retrieval in optically deep and complex waters from satellite imagery" Remote Sens. Environ., 118, pp. 116-126.

12. Schultz GA (1996). "Remote sensing applications to hydrology: Runoff” Hydrol. Sci. J., 41(4), pp. 453-475.

13. Sanyal J, Lu X X (2004). "Application of remote sensing in flood management with special reference to monsoon Asia: a review" Nat. Hazards, 33, pp. 283-301.

14. McVicar TR, Jupp DLB (1998). "The current and potential operational uses of remote sensing to aid decisions on drought exceptional circumstances in Australia: A review" Agric. Syst., 57 (3), pp. 399-468.

15. Ozdogan M, Yang Y, Allez G, Cervantes C (2010). "Remote Sensing of Irrigated Agriculture: Opportunities and Challenges" Remote Sens., 2, pp. 2274-2304. doi:10.3390/ rs 2092274

16. Belmonte $\mathrm{AC}$, Jochum $\mathrm{AM}$, Garcìa $\mathrm{AC}$, Rodrìguez $\mathrm{AM}$, Fuster PL (2005). "Irrigation management from space: towards user-friendly products" Irrig. Drain. Sys., 19, pp. 337-353.

17. Rango A (1994). "Application of remote sensing methods to hydrology and water resources" Hydrol. Sci. J., 39 (4), pp. 309-320.

18. Sharma KD, Singh S, Singh N, Kalla AK (1989). "Role of satellite remote sensing for monitoring of surface water resources in an arid environment" Hydrol. Sci. J., 34(5), pp. 531-537.

19. Brisco B, Short N, van der Sanden J, Landry R, Raymond D (2009). "A semi-automated tool for surface water mapping with RADARSAT-1" Can. J. Remote Sens., 35(4). doi:336-344, 10.5589/m09-025.

20. Hess LL, Melack JM, Simonett DS (1990). "Radar detection of flooding beneath the forest canopy-A review" Int. J. Remote Sens., 11 (7), pp. 1313-1325.

21. Martinez J-M, Le Toan T (2007). "Mapping of flood dynamics and spatial distribution of vegetation in the Amazon floodplain using multitemporal SAR data" Remote Sens. Environ., 108, pp. 209-223. doi:10.1016/j. rse.2006.11.012.

22. Rosenquist A, Finlayson CM, Lowry J, Taylor D (2007). "The potential of longwavelength satellite-borne radar to support implementation of the Ramsar Wetlands Convention" Aquat. Conserv.-Mar. Freshwater Ecosyst., 17 (3), pp. 229-244.

23. Leblanc M, Lemoalle J, Bader J-C, Tweed S, Mofor L (2011). "Thermal remote sensing of water under flooded vegetation: New observations of inundation patterns for the 'Small' Lake Chad" J. Hydrol., 404, pp. 87-98. doi:10.1016/j.jhydrol.2011.04.023.

24. Gibson PJ, Power CH (2000). Introductory Remote Sensing-Digital Image Processing and Applications. Routledge Pub., London.

25. Arkin PA, Meisner BN (1987). “The relationship between large-scale convective rainfall and cold cloud over the western hemisphere during 1982-84" Mont. Wea. Rev., 115, pp. 51-74.

26. Wexler R, Swingle DM (1947). "Radar storm detection" Bul. Amer. Met. Sco., 28, pp. 159-167.

27. Marshall JS, Langille RC, Palmer WM (1947). "Measurement of rainfall by radar" J. Met., 4(6), pp. 186-192.

28. Chandrasekar V, Cifelli R (2012). "Concepts and principles of rainfall estimation from radar: Multi sensor environment and data fusion" Indian J. Radio \& Space Phys., 41, pp. 389-402.

29. Greenwald TJ, Stephens GL, Haar THV, Jackson D (1993). "A physical retrieval of cloud liquid water over the global 
oceans using Special Sensor Microwave/Imager (SSM/I) observations" J. Geophys. Res., 98 (D10), pp. 18471-18488.

30. Rango A, Martinec J, Chang ATC, Foster JL (1989). “Average areal water equivalent of snow in a mountain basin using microwave and visible satellite data" IEEE Trans. Geosci. Remote Sens, , 2(6), pp. 740-745.

31. Kelly RE, Chang AT, Tsang L, Foster JL (2003). "A prototype AMSR-E global snow area and snow depth algorithm" IEEE Trans. Geosci. Remote Sens., 41 (2). pp. 230-242.

32. Rosenthal W, Dozier J (1996). "Automated mapping of montane snow cover at subpixel resolution from the Landsat Thematic Mapper” Water Resour. Res., 32 (1), pp. 115-130.

33. Akyürek Z, Sorman AÜ (2002). "Monitoring snow-covered areas using NOAAAVHRR data in the eastern part of Turkey" Hydrolo. Sci. J., 47 (2), pp. 243-252.

34. Rittger K, Painter TH, Dozier J (2013). "Assessment of methods for mapping snow cover from MODIS" Adv. Water. Resour., 51, pp. 367-380. doi:10.1016/j. advwatres.2012.03.002.

35. Huang L, Li Z, Tian BS, Chen Q, Liu JL, Zhang R (2011). "Classification and snow line detection for glacial areas using the polarimetric SAR image" Remote Sens. Environ., 115, pp. 1721-1732. doi:10.1016/j.rse.2011.03.004.

36. Rott E, Nagler T (1995). "Monitoring temporal dynamics of snowmelt with ERS-1 SAR" In Proceedings of IGARSS'95, Firenze (Italy), July 1995 (Piscataway: IEEE), pp. $1747-1749$.

37. Matzler C (1987) "Applications of the interaction of microwaves with the natural snow cover" Remote Sens. Rev., 2, pp. 259-387.

38. Baghdadi N, Fortin JP, Bernier M (1999). "Accuracy of wet snow mapping using simulated Radarsat backscattering coefficients from observed snow cover characteristics" Int. J. Remote Sens., 20 (10), pp.: 2049-2068.

39. Njoku EG, Jackson TJ, Lakshmi V, Chan TK, Nghiem SV (2003). "Soil Moisture retrieval from AMSR-E" IEEE Trans. Geosci.Remote Sens., 41 (2), pp. 215-229.

40. Wigneron JP, Calvet JC, Pellarin T, Griend AAV, Berger M, Ferrazzoli P (2003). "Retrieving near-surface soil moisture from microwave radiometric observations: current status and future plans" Remote Sens. Environ., 85, pp. 489-506. doi:10.1016/S0034-4257(03)00051-8.

41. Verstraeten WW, Veroustraete F, van der Sande CJ, Grootaers I, Feyen J (2006). "Soil moisture retrieval using thermal inertia, determined with visible and thermal spaceborne data, validated for European forests" Remote Sens. Environ., 101, pp. 299-314, doi:10.1016/j.rse. 2005.12.016.

42. Cai G, Xue Y, Hu Y, Wang Y, Guo J, Luo Y, Wu C, Zhong S, Qi S (2007). "Soil moisture retrieval from MODIS data in Northern China Plain using thermal inertia model" Int. J. Remote Sens., 28 (16), pp. 3567-3581.

43. Schmugge T, Jackson TJ, Kustas WP, Wang JR (1992). "Passive microwave remote sensing of soil moistureResults from Hapex, Fife and Monsoon-90" ISPRS J. Photogramm. Remote Sens., 47, pp. 127-143, doi:10.1016/0924-2716(92)90029-9.
44. Sellers PJ, Hall FG, Asrar G, Strebel DE, Murphy RE (1992). "An overview of the 1 st International Satellite Land Surface Climatology Project (ISLSCP) Field Experiment (FIFE)" J. Geophys. Res., 97, pp. 18345-18371.

45. Jackson TJ, Levine DM, Griffis AJ, Goodrich DC, Schmugge TJ, Swift CT, Oneill PE (1993). "Soil moisture and rainfall estimation over a semiarid environment with the ESTAR microwave radiometer" IEEE Trans. Geosci. Remote Sens., 31, pp. 836-841, doi:10.1109/36. 239906.

46. Narayan U, Lakshmi V, Njoku EG (2004). "Retrieval of soil moisture from passive and active L/S band sensor (PALS) observations during the Soil Moisture Experiment in 2002 (SMEX02)” Remote Sens. Environ., 92, pp. 483-496, doi:10.1016/j.rse.2004.05.018.

47. Crosson WL, Limaye AS, Laymon CA (2005). "Parameter sensitivity of soil moisture retrievals from airborne $\mathrm{C}$ - and X-band radiometer measurements in SMEX02" IEEE Trans. Geosci. Remote Sens., 43, pp. 2842-2853, doi:10.1109/TGRS.2005.857916.

48. Haider SS, Said S, Kothyari UC, Arora MK (2004). "Soil moisture estimation using ERS 2 SAR data: A case study in the Solani River catchment" Hydrol. Sci. J., 49(2), pp. 323-334.

49. Shoshani M, Svoray T, Curran PJ, Foody GM, Perevolotsky A (2000). "The relationship between ERS-2 SAR backscatter and soil moisture: Generalization from a humid to semiarid transect" Int. J. Remote Sens., 21 (11), pp. 2337-2343.

50. Wagner W, Blöschl G, Pampaloni P, Calvet JC, Bizzarri B, Wigneron JP, Kerr Y (2007). “Operational readiness of microwave remote sensing of soil moisture for hydrologic applications" Nordic Hydrol., 38(1), pp. 1-20.

51. Jackson TJ, Levine DM, Swift CT, Schmugge TJ, Schiebe FR(1995). "Large-area mapping of soil moisture using the ESTAR passive microwave radiometer in Washita92" Remote Sens. Environ., 54, pp. 27-37. doi:10.1016/0034-4257(95)00084-E.

52. Wigneron JP, Schmugge T, Chanzy A, Calvet JC, Kerr Y (1998). "Use of passive microwave remote sensing to monitor soil moisture" Agronomie, 18, pp. 27-43.

53. Das NN, Mohanty BP, Cosh MH, Jackson TJ (2008). "Modeling and assimilation of root zone soil moisture using remote sensing observations in Walnut Gulch Watershed during SMEX04" Remtoe Sens. Environ., 112, pp. 415-429. doi:doi:10.1016/j.rse.2006.10.027.

54. Njoku E, Entekhabi D (1996). "Passive microwave remote sensing of soil moisture” J. Hydrolo., 184, pp. 101-129.

55. Kerr YH (2007). "Soil moisture from space: Where are we?” Hydrogeolo. J., 15, pp. 117-120. doi:10.1007/s10040006-0095-3.

56. Yanmin Y, Wei N, Youqi C, Yingbin H, Pengqin T (2010). "Soil Moisture Monitoring Using Hyper-Spectral Remote Sensing Technology" In 2010 Second IITA International Conference on Geosci. Remote Sens., pp. 373-376, IEEE.

57. Kirk JTO (1983). Light and Photosynthesis in Aquatic Ecosystems, Cambridge University Press, Cambridge, United Kingdom. 
58. Koponen S, Pulliainen J, Kallio K, Hallikainen M (2002). "Lake water quality classification with airborne hyperspectral spectrometer and simulated MERIS data" Remote Sens. Environ., 79, pp. 51-59.

59. Giardino C, Bresciani M, Villa P, Martinelli A (2010). "Application of remote sensing in water resources management: The case study of Lake Trasimeno, Italy" Water Resour.Manage., 24, pp. 3885-3899. doi:10.1007/s11269010-9639-3.

60. Brezonik P, Menken KD, Bauer M (2005). "Landsatbased remote sensing of lake water quality characteristics, including chlorophyll and colored dissolved organic matter (CDOM)" Lake and Reservoir Manage., 21 (4), pp. 373-382.

61. Lesht BM, Barbiero RP, Warren GJ (2013). "A band-ratio algorithm for retrieving open-lake chlorophyll values from satellite observations of the Great Lakes" J. Great Lakes Res., 39, pp. 138-152.

62. Brando VE, Dekker AG (2003). "Satellite hyperspectral remote sensing for estimating estuarine and coastal water quality” IEEE Trans. Geosci. Remote Sens., 41 (6), pp. 1378-1387.

63. Santini F, Alberotanza L, Cavalli RM, Pignatti S (2010) "A two-step optimization procedure for assessing water constituent concentrations by hyperspectral remote sensing techniques: An application to the highly turbid Venice lagoon waters" Remote Sens. Environ., 114, pp. 887-898. doi:10.1016/j.rse.2009.12.001.

64. Alcântara EH, Stech JL, Lorenzzetti JA, Bonnet MP, Casamitjana X, Assireu AT, Novo EMLM (2010). "Remote sensing of water surface temperature and heat flux over a tropical hydroelectric reservoir" Remote Sens. Environ., 114 (11), pp. 2651-2665.

65. Politi E, Cutler MEJ, Rowan JS (2012). "Using the NOAA Advanced Very High Resolution Radiometer to characterize temporal and spatial trends in water temperature of large European lakes" Remote Sens. Environ., 126, pp. 1-11. doi:/10.1016/j.rse.2012.08.004.

66. Ritchie JC, Schiebe FR (2000). Water quality, Remote Sensing in Hydrology and Water Management (G.A. Schultz and E.T. Engman, Ed.), Springer-Verlag, Berlin, Germany.

67. Ritchie JC (2000). Soil Erosion, Remote Sensing in Hydrology and Water Management (G.A. Schultz and E.T. Engman, Ed.), Springer-Verlag, Berlin, Germany.

68. Ritchie JC, McHenry JR, Schiebe FR, Wilson RB (1974). "The relationship of reflected solar radiation and the concentration of sediment in the surface water of reservoirs" Remote Sensing of Earth Resources Vol. III (F. Shahrokhi, Ed.), The University of Tennessee Space Institute, Tullahoma, Tennessee.

69. Harding LW, Itsweire EC, Esaias WE (1995). "Algorithm development for recovering chlorophyll concentrations in the Chesapeake Bay using aircraft remote sensing, 1989-91" Photogram. Eng. Remote Sens., 61(2), pp. 177-185.

70. Volpe V, Silvestri S, Marani M (2011). "Remote sensing retrieval of suspended sediment concentration in shallow waters" Remote Sens. Environ., 115, pp. 44-54. doi:10.1016/j.rse.2010.07.013.

71. Lee ZP, Carder KL, Mobley CD, Steward RG, Patch JS (1998). "Hyperspectral remote sensing for shallow waters: 1. A semi analytical model" Applied Optics, 37(27).

72. Lee ZP, Carder KL, Mobley CD, Steward RG, Patch JS (1999). "Hyperspectral remote sensing for shallow waters: 2. Deriving bottom depths and water properties by optimization" Applied Optics, 38(18).

73. Wu G, de Leeuw J, Liu Y (2009). "Understanding seasonal water clarity dynamics of lake dahuchi from in situ and remote sensing data" Water Resour. Manag., 23, pp. 1849-1861.

74. Gons HJ, Auer MT, Effler SW (2008). "MERIS satellite chlorophyll mapping of oligotrophic and eutrophic waters in the Laurentian Gt Lakes" Remote Sens. Environ., 112, pp. 4098-4106.

75. Thiemann S, Kaufmann H (2002). "Lake water quality monitoring using hyperspectral airborne data-A semiempirical multisensor and multitemporal approach for the Mecklenburg Lake District, Germany" Remote Sens. Environ., 8, pp. 228-237.

76. Froidefond J, Gardel L, Guiral D, Parra M, Ternon J(2002). "Spectral remote sensing reflectances of coastal waters in French Guiana under the Amazon influence" Remote Sens. Environ., 80, pp. 225-232.

77. Hakvoort H, De Haan J, Jordans R, Vos R, Peters S, Rijkeboer M (2002). “Towards airborne remote sensing of water quality in the Netherlands-validation and error analysis" J. Photogr. Remote Sens. 57, pp. 171-183.

78. Vos RJ, Hakvoort JHM, Jordansm RWJ, Ibelings BW (2003). "Multiplatform optical monitoring of eutrophication in temporally and spatially variable lakes" Sci. Total Environ., 312, pp. 221-243.

79. Stumpf RP (2001). "Applications of satellite ocean color sensors for monitoring and predicting harmful algal blooms” Hum. Ecol. Risk Assess., 7, pp. 1363-1368.

80. Lesser MP, Mobley CD (2007). "Bathymetry, water optical properties, and benthic classification of coral reefs using hyperspectral remote sensing imagery" Coral Reefs. 26, pp. 819-829. Doi: 10.1007/s00338-007-0271-5.

81. Pietroniro A, Prowse TD (2002). "Applications of remote sensing in hydrology" Hydrol. Process., 16, pp. 1537-1541.

82. Sekhar KR, Rao BV (2002). "Evaluation of sediment yield by using remote sensing and GIS: A case study from the Phulang Vagu watershed, Nizamabad District (AP), India" Int. J. Remote Sens., 23 (20), pp. 4499-4509.

83. Chowdary VM, Ramakrishnan D, Srivastava YK, Chandran V, Jeyaram A (2009). "Integrated Water Resource Development Plan for Sustainable Management of Mayurakshi Watershed, India using Remote Sensing and GIS" Water Resour Manag., 23, pp. 1581-1602. doi:10.1007/s11269-008-9342-9.

84. Mauser W, Schädlich S (1998). "Modelling the spatial distribution of evapotranspiration on different scales using remote sensing data" J. Hydrol., 212-213, pp. 250-267. 
85. Russell GD, Hawkins CP, O’Neill MP (2004). “The Role of GIS in Selecting Sites for Riparian Restoration Based on Hydrology and Land Use" Restor. Ecol., 5(4S), pp. 56-68. doi:10.1111/j.1526-100X.1997.00056.x.

86. Rao NR (2008). "Development of a crop-specific spectral library and discrimination of various agricultural crop varieties using hyperspectral imagery" Int. J. Remote Sens., 29 (1), pp. 131-144.

87. Courault D, Seguin B, Olioso A (2005). "Review on estimation of evapotranspiration from remote sensing data: From empirical to numerical modeling approaches" Irrig. and Drain. Syst., 19, pp. 223-249.

88. Jackson RD, Reginato RJ, Idso SB (1977). "Wheat canopy temperature: A practical tool for evaluating water requirements" Water Resour. Res., 13, pp. 651-656.

89. Bastiaanssen WGM, Menenti M, Feddes RA, Holtslag AA (1998). "A remote sensing surface energy balance algorithm for land (SEBAL)" J. Hydrol., 212-213, pp. 198-212.

90. Allen RG, Pereira LS, Raes D, Smith M (1998). "Crop evapotranspiration: guidelines for computing crop water requirements" Irrigation and Drainage Paper 56, United Nations FAO, Rome.

91. Olioso A, Chauki,H, Courault D, Wigneron JP (1999). "Estimation of Evapotranspiration and Photosynthesis by Assimilation of Remote Sensing Data into SVAT Models" Remote Sens. Environ., 68, pp. 341-356.

92. Allen RG, Tasumi M, Morse A, Trezza R (2005). "A Landsat-based energy balance and evapotranspiration model in Western US water rights regulation and planning" Irrig. and Drain. Syst., 19(3/4), pp. 251-268.

93. Neale C, Jayanthi H, Wright JL (2005). "Irrigation water management using high resolution airborne remote sensing" Irrig. Drain. Syst., 19(3/4), pp. 321-336.

94. Mu Q, Zhao M, Running SW (2011). "Improvements to a MODIS global terrestrial evapotranspiration algorithm" Remote Sens. Environ., 115, pp. 1781-1800. doi:10.1016/j. rse.2011.02.019.

95. Kustas WP, Norman J, Anderson MC, French AN (2003). "Estimating subpixel surface temperatures and energy fluxes from the vegetation index radiometric temperature relationship" Remote Sens. Environ., 85, pp. 429-440.

96. Takeuchi K, Ao T, Ishidaira H (1999). "Introduction of block-wise use of TOPMODEL and Muskingum-Cunge method for the hydroenvironmental simulation of a large ungauged basin” Hydrol. Sci. J., 44(4), pp. 633-646.

97. Papadakis I, Napiorkowski J, Schultz G A(1993). "Monthly runoff generation by nonlinear model using multispectral and multitemporal satellite imagery" Adv. Space Res. 13(5).

98. SCS (1972). National Engineering Handbook, Section 4Hydrology. U.S Department of Agriculture, Washington DC.

99. Reshmidevi TV, Jana R, Eldho TI (2008). "Geospatial estimation soil moisture in rain-fed paddy fields using SCS-CN based model” Agri. Water Manage., 95 (4), pp. 447-457.
100. O’Donnel GM, Czajkowski KP, Dubayah RO, Lettenmaier DP (2000). "Macroscale hydrological modeling using remotely sensed inputs: Application to the Ohio River Basin" J. Geophys. Res., 105 (D10), pp. 12499-12516.

101. Crow WT, Ryu D (2009). "A new data assimilation approach for improving runoff prediction using remotely-sensed soil moisture retrievals" Hydrol. Earth Syst. Sci., 13, pp. 1-16.

102. Houser PR, Shuttleworth WJ, Famiglietti JS, Gupta HV, Syed KH, Goodrich DC (1998). "Integration of soil moisture remote sensing and hydrologic modeling using data assimilation” Water Resour. Res., 34 (12), pp. 3405-3420.

103. Borchardt S, Trauth MH (2012). "Remotely-sensed evapotranspiration estimates for an improved hydrological modeling of the early Holocene mega-lake Suguta, northern Kenya Rift" Palaeogeography, Palaeoclimatology, Palaeoecology, 361-362, pp. 14-20.

104. Jacobs JM, Myers DA, Whitfield BM (2007). "Improved rainfall/runoff estimates using remotely sensed soil moisture" J. Am. Water Resour. Assoc., 39(2), pp. 313-324.

105. Gineste P, Puech C, Mérot P (1998). "Radar remote sensing of the source areas from the Coët-Dan catchment" Hydrol. Process., 12, pp. 267-284.

106. Durand M, Rodríguez E, Alsdorf DE, Trigg M (2010). "Estimating river depth from remote sensing swath interferometry measurements of river height, slope, and width" IEEE J. Sel. Top. Appl. Earth Obs. Remote Sens., 3 (1), pp. 20-31.

107. Bjerklie DM, Moller D, Smith LC, Dingman SL (2005). "Estimating discharge in rivers using remotely sensed hydraulic information” J. Hydrol., 309, pp. 191-209.

108. Ungani LS, Kogan FN (1998). "Drought monitoring and corn yield estimation in southern Africa from AVHRR data” Remote Sens. of Environ., 63, pp. 219-232.

109. Rasmussen MS (1997). "Operational yield forecast using AVHRR NDVI data: Reduction of environmental and inter-annual variability" Int. J. Remote Sens., 18 (5), pp. 1059-1077.

110. Kalubarme MH, Potdar MB, Manjunath KR, Mahey RK, Siddhu SS (2003). "Growth profile based crop yield models: A case study of large area wheat yield modelling and its extendibility using atmospheric corrected NOAA AVHRR data” Int. J. Remote Sens., 24(10), pp. 2037-2054.

111. Thenkabail PS (2003). "Biophysical and yield information for precision farming from near-real-time and historical Landsat TM images" Int. J. Remote Sens., 24, pp. 839-877.

112. Choudhary SS, Garg PK, Ghosh SK (2012). "Mapping of Agriculture Drought using Remote Sensing and GIS" Int. J. Sci. Eng. Technol., 1(4), pp. 149-157.

113. Ray SS, Pokharna SS, Ajai (1999). "Cotton yield estimation using agrometeorological model and satellitederived spectral profile” Int. J. Remote Sens., 20 (14), pp. 2693-2702.

114. Ghosh TK (1997). "Investigation of drought through digital analysis of satellite data and Geographical Information Syst.” Theor. Appl. Climatol., 58, pp. 105-112. 
115. Moulin S, Bondeau A, Delecolle R (1998). "Combining agricultural crop models and satellite observations: from field to regional scales" Int. J. Remote Sens., 19(6), pp. 1021-36.

116. Wan Z, Wang P, Li X (2004). "Using MODIS land surface temperature and Normalized Difference Vegetation Index products for monitoring drought in the southern Great Plains, USA" Int. J. Remote Sens., 25(1), pp. 61-72.

117. Gu Y, Brown JF, Verdin JP, Wardlow B (2007). "A fiveyear analysis of MODIS NDVI and NDWI for grassland drought assessment over the central Great Plains of the United States" Geophys. Res. Lett., 34 (L06407). doi:10.1029/2006GL029127.

118. Bhavsar PD (1984). "Review of remote sensing applications in hydrology and water resource management in India” Adv. Space Res., 4(11), pp. 193-200.

119. Wang Y, Colby JD, Mulcahy KA (2002). "An efficient method for mapping flood extent in a coastal flood plain using Landsat TM and DEM data" Int. J. Remote Sens., 23(18), pp. 3681-3696.

120. Sinha R, Bapalu GV, Singh LK, Rath B (2008). “Flood risk analysis in the Kosi River Basin, north Bihar using multi-parametric approach of analytical hierarchy process (AHP)" J. Indian Soc. Remote Sens., 36, pp. 335-349.

121. Chatterjee C, Kumar R, Mani P (2003). "Delineation of surface waterlogged areas in parts of Bihar using IRS-1C LISS-III data” J. Indian Soc. Remote Sens., 31, pp. 57-65.

122. Oberstadler R, Honsch H, Huth D (1997). "Assessment of the mapping capabilities of ERS-1 SAR data for flood mapping: A case study of Germany" Hydrol. Process., 10 (10), pp. 1415-1425.

123. Islam MM, Sadu K (2001). "Flood damage and modelling using satellite remote sensing data with GIS: Case study of Bangladesh" In: Remote Sensing and Hydrology 2000 (Ritchie J et al. Eds.), IAHS Publication, Oxford, pp. 455-458.

124. Ali A, Quadir DA (1987). "Agricultural hydrologic and oceanographic studies in Bangladesh with NOAA AVHRR data” Int. J .Remote Sens., 8 (6), pp. 917-925.

125. Brakenridge R, Anderson E (2006). "MODIS-based flood detection, mapping and measurement: the potential for operational hydrological applications" In: Transboundary Floods: Reducing Risks Through Flood Management (Marsalek J et al. Eds.), Springer, Netherlands, pp. 1-12.

126. Sakamoto T, Nguyen NV, Kotera A, Ohno H, Ishitsuka N, Yokozawa M (2007). "Detecting temporal changes in the extent of annual flooding within the Cambodia and the Vietnamese Mekong Delta from MODIS timeseries imagery" Remote Sens. Environ., pp. 295-313. doi:10.1016/j.rse.2007.01.011.

127. Brivio PA, Colombo R, Maggi M, Tomasoni R (2002). "Integration of remote sensing data and GIS for accurate mapping of flooded areas" Int. J. Remote Sens., 23(3), pp. 429-441.

128. Liu Z L, Huang F, Li LY, Wan E P (1999). “Dynamic monitoring and damage evaluation of flood in northwest Jilin with remote sensing" In: Proc. 20th Asian Conference of Remote Sensing, Hong Kong, 22-25 November.
129. Long NT, Trong BD (2001). "Flood monitoring of Mekong River Delta, Vietnam using ERS SAR Data" In: Proc. 22nd Asian Conference of Remote Sensing, Singapore, 5-9 November.

130. Smith LC (1997). "Satellite remote sensing of river inundation area, stage, and discharge: A review" Hydrol. Process., 11 (10), pp. 1427-1439.

131. Showalter PS, Ramspott M, Mortan D, Prosperie L, Walter L (1999). "The use of remote sensing in detecting and analyzing natural hazards and disasters, 1972-1998: A partially annotated bibliography" Occasional Paper No.1, The James and Marilyn Lovell Center for Environmental Geography and Hazards Research, Department of Geography, Southwest Texas University, Texas.

132. Bhatt CM, Rao GS, Manjushree P, Bhanumurthy V (2010). "Space based disaster management of 2008 Kosi Floods, North Bihar, India. J. Indian. Soc. Remote Sens., 38, pp. 99-106.

133. Honda KC, Francis XJ, Sah V P (1997). "Flood monitoring in central plain of Thailand using JERS-1 SAR data" In: Proc. 18th Asian Conference of Remote Sensing, Malaysia, 20-24 October.

134. Chen P, Liew SC, Lim H (1999). "Flood detection using multitemporal Radarsat and ERS SAR data" Proc. 20th Asian Conference of Remote Sensing, Hong Kong, 22-25 November.

135. Khan SI, Hong Y, Wang J, Yilmaz KK, Gourley JJ, Adler RF, Brakenridge GR, Policelli F, Habib S, Irwin D (2011). "Satellite remote sensing and hydrologic modeling for flood inundation mapping in Lake Victoria Basin: Implications for hydrologic prediction in ungauged basins" IEEE Trans. Geosci. Remote Sens., 49 (1), pp. 85-95.

136. Bhanumurthy V, Manjusree P, Srinivasa Rao G (2010). "Flood disaster management" Chapter 12, Remote Sens. Applications (Roy, P.S., Dwivedi, R.S., Vijayan, D, Eds.), NRSC, Hyderabad, India.

137. Batista GT, Hixson MM, Bauer ME (1985). "LANDSAT MSS crop classification performance as a function of scene characteristics" Int. J. Remote Sens., 6 (9), pp. 1521-1533.

138. Dutta S, Patel NK, Medhavy TT, Srivastava SK, Mishra N, Singh KRP (1998). "Wheat crop classification using multidate IRS LISS-I data" Photonirvachak-J. Indian Soc. Remote Sens., 26 (1-2), pp. 7-14.

139. Thenkabail PS, Dheeravath V, Biradar CM, Gangalakunta ORP, Noojipady P, Gurappa C, Velpuri M, Gumma M, Li Y (2009). "Irrigated area maps and statistics of India using remote sensing and national statistics" Remote Sens., 1, pp. 50-67.

140. Ozdogan M, Gutman G (2008). "A new methodology to map irrigated areas using multi-temporal MODIS and ancillary data: An application example in the continental US” Remote Sens. Environ., 112, pp. 3520-3537.

141. Eckhardt DW, Verdin JP, Lyford GR (1990). "Automated update of an irrigated lands GIS using SPOT HRV imagery" Photogramm. Eng. Remote Sens., 56, pp. 1515-1522. 
142. Biggs TW, Thenkabail PS, Gumma MK, Scott CA, Parthasaradhi GR, Turral HN (2006). "Irrigated area mapping in heterogeneous landscapes with MODIS time series, ground truth and census data, Krishna Basin, India" Int. J. Remote Sens., 27 (19), pp. 4245-4266.

143. Droogers P, Bastiaanssen W (2002). "Irrigation performance using hydrological and remote sensing modeling" J. Irrig. Drain. Eng., 128 (1), pp. 11-18.

144. Bastiaanssen WGM (1998). Remote Sensing in Water Resources Management: The State of the Art, International Water Management Institute (IWMI), Colombo, Sri Lanka.

145. Roerink GJ, Bastiaanssen WGM, Chambouleyron J, Menenti M (1996). "Relating Crop Water Consumption to Irrigation Water Supply by Remote Sensing” Water Resour. Manag., 11, pp. 445-465.

146. Ahmad MD, Turral H, Nazeer A (2009). "Diagnosing irrigation performance and water productivity through satellite remote sensing and secondary data in a large irrigation system of Pakistan” Agric. Water Manag., 96, pp. 551-564.

147. Ray SS, Dadhwal VK, Navalgund RR (2002). "Performance evaluation of an irrigation command area using remote sensing: A case study of Mahi command, Gujarat, India” Agric. Water Manag., 56, pp. 81-91.

148. DEMETER (2002). Demonstration of Earth Observation Technologies in Routine Irrigation Advisory Services. http:// www.demeter-ec.net.

149. Jasrotia AS, Majhi A, Singh S (2009). "Water balance approach for rainwater harvesting using remote sensing and GIS Techniques, Jammu Himalaya, India" Water Resour. Manag., 23, pp. 3035-3055. doi:10.1007/s11269009-9422-5.

150. Kumar GM, Agarwal AK, Bali R (2008). "Delineation of potential sites for water harvesting structures using remote sensing and GIS” J. Indian Soc. Remote Sens., 36, pp. 323-334.

151. Mbilinyi BP, Tumbo SD, Mahoo HF, Mkiramwinyi FO (2007). "GIS-based decision support system for identifying potential sites for rainwater harvesting" Phys. and Chem. Earth, 32, pp. 1074-1081.

152. Elewa HH, Qaddah AA, El-Feel AA (2012). “Determining potential sites for runoff water harvesting using remote sensing and Geographic Information Systems-based modeling in Sinai” Am. J. Environ. Sci., 8 (1), pp. 42-55.
153. Saxena RK, Verma KS, Chary GR, Srivastrava R, Batrhwal AK (2000). "IRS-1C data application in watershed characterization and management" Int. J. Remote Sens., 21 (17), pp. 3197-3208.

154. Khan MA, Gupta VP, Moharana PC (2001). "Watershed prioritization using remote sensing and geographical information system: A case study from Guhiya, India" J. Arid Environ., 49, pp. 465-475.

155. Biswas S, Sudhakar S, Desai VR (1999). "Prioritisation of subwatersheds based on morphometric analysis of drainage basin: A remote sensing and GIS approach" Photonirvachak-J. Indian Soc. Remote Sens., 27 (3), pp. 155-166.

156. MeijerinkAM (1996).“Remotesensing application to hydrology: Groundwater” Hydrol. Sci. J., 41(4), pp. 549-561.

157. Brunner P, Franssen H-JH, Kgotlhang L, Bauer-Gottwein P, Kinzelbach W (2007), "How can remote sensing contribute in groundwater modeling?” Hydrogeol. J., 15, pp. 5-18.

158. Becker MW (2006). "Potential for satellite remote sensing of ground water” Groundwater, 44(2), pp. 306-318.

159. Rodell M, Velicogna I, Famiglietti J S (2009). "Satellitebased estimates of groundwater depletion in India" Nature, 460, pp. 999-1002.

160. Yeh PJ-F, Swenson SC, Famiglietti JS, Rodell M (2006). "Remote sensing of groundwater storage changes in Illinois using the Gravity Recovery and Climate Experiment (GRACE)" Water Resour. Res., 42 (W12203). doi:10.1029/2006/WR005374.

161. Krishnamurthy J, Venkatesa Kumar N, Jayaraman V, Manivel M (1996). "An approach to demarcate ground water potential zones through remote sensing and a geographical information system" Int. J. Remote Sens., 17(10), pp. 1867-1884.

162. Krishnamurthy J, Mani A, Jayaraman V, Manivel M (2000). "Groundwater resources development in hard rock terrain-An approach using remote sensing and GIS techniques" Int. J. Applied Earth Obs. Geoinformation, 2(3-4), pp 204-215.

163. Rai B, Tiwari A, Dubey VS (2005). Identification of groundwater prospective zones by using remote sensing and geoelectical methods in Jharia and Raniganj coalfields, Dhanbad district, Jharkhand state. J. Earth System Sci., 114 (5), pp 515-522.

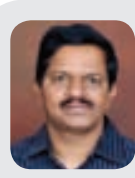

Prof. D. Nagesh Kumar is working as Professor in the Department of Civil Engineering, Indian Institute of Science, Bangalore, since May 2002. Earlier he worked in IIT, Kharagpur and NRSC, Hyderabad. His research interests include Climate Hydrology, Water Resources Systems, ANN, Evolutionary Algorithms, Fuzzy logic, MCDM and Remote Sensing \& GIS applications in water resources engineering. He has co-authored two text books titled "Multicriterion Analysis in Engineering and Management" published by PHI, New Delhi and "Floods in a Changing Climate: Hydrologic Modeling", published by Cambridge University Press, U.K. (Homepage: http://civil.iisc.ernet.in/ nagesh/)

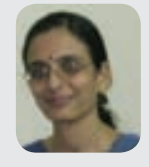

Dr. T.V. Reshmidevi is working as a Post-Doctoral Fellow in the Department of Civil Engineering, Indian Institute of Science, Bangalore, since December 2009. She has obtained M.Tech and Ph.D degrees from Indian Institute of Technology Bombay. Her research interests include irrigation management, hydrologic modeling, climate change assessment, and remote sensing \& GIS applications in water resources management. 
